\title{
Effects of condensed tannins in conifer leaves on the composition and activity of the soil microbial community in a tropical montane forest
}

\section{AUTHOR(S):}

Ushio, Masayuki; Balser, Teri C.; Kitayama, Kanehiro

\section{CITATION:}

Ushio, Masayuki ... [et al]. Effects of condensed tannins in conifer leaves on the composition and activity of the soil microbial community in a tropical montane forest. Plant and Soil 2013, 365(1-2): 157-170

\section{ISSUE DATE:}

2013-04

URL:

http://hdl.handle.net/2433/173119

\section{RIGHT:}

The final publication is available at www.springerlink.com; This is not the published version. Please cite only the published version.; この論文 は出版社版でありません。引用の際には出版社版をご確認ご利用くだ さい。 
1 Prepared for Plant and Soil, 2012/6/27

2 Title: Effects of condensed tannins in conifer leaves on the composition and activity

3 of the soil microbial community in a tropical montane forest

4

5 Names of Authors: Masayuki Ushio ${ }^{1} *$, Teri C. Balser ${ }^{2, \dagger}$, Kanehiro Kitayama $^{1,3}$

6

7 Affiliations: ${ }^{1}$ Center for Ecological Research, Kyoto University, 2-509-3 Hirano, Otsu,

8 Shiga, 520-2113, JAPAN. ${ }^{2}$ Department of Soil Science, University of

9 Wisconsin-Madison, Madison, WI 53706, USA. ${ }^{3}$ Graduate School of Agriculture,

10 Kyoto University, Kitashirakawa, Oiwake, Sakyo-ku, Kyoto 606-8502, JAPAN.

$11 \dagger^{\dagger}$ current address, Department of Soil and Water Science, the University of Florida IFAS,

12 USA

13

$14 *$ Corresponding author.

15 Tel: $+81-77-549-8215$

16 Fax: +81-77-549-8201

17 e-mail: ushima@ecology.kyoto-u.ac.jp

18 
19

20

21 Background and Aims Condensed tannins, a dominant class of plant secondary

22

23

24

25

26

27

28

29

30

31

32

33

34

35

36

37

38

39

\section{Abstract}

metabolites, play potentially important roles in plant-soil feedbacks by influencing the soil microbial community. Effects of condensed tannins on the soil microbial community and activity were examined by a short-term tannin-addition experiment under field and laboratory conditions.

Methods Condensed tannins were extracted from the leaves of a dominant conifer (Dacrydium gracilis) in a tropical montane forest on Mt. Kinabalu, Borneo. The extracted tannins were added to soils beneath the conifer and a dominant broadleaf (Lithocarpus clementianus) to evaluate the dependence of the response to tannin addition on the initial composition of the soil microbial community.

Results Enzyme activities in the field tannin-addition treatment were lower than in the deionized-water treatment. Carbon and nitrogen mineralization were also inhibited by tannin-addition. The fungi-to-bacteria ratio after tannin-addition was higher compared with the distilled-water treatment in the laboratory experiment.

Conclusions Based on our results, we suggest that the higher concentration of condensed tannins in the leaf tissues of Dacrydium than in those of Lithocarpus is a factor influencing the microbial community and activity. This may have influences on subsequent plant performance, which induces plant-soil feedback processes that can control dynamics of the tropical montane forest ecosystem. 
$40 \quad$ Key-words

41 Condensed tannins; Conifer; Plant-soil feedback; Soil enzyme activity; Soil microbial

42 community; Tropical montane forest

43 


\section{Introduction}

Condensed tannins, a dominant class of plant secondary metabolites, are often found in plant tissues in great abundance (Hartley and Jones 1997). For example, tree leaves often contain 10-20\% of condensed tannins by dry weight (Kuiters 1990; Ushio and Adams 2011). Due to their specific biochemical properties, these metabolites have a large effect on soil mineralization processes, through their influence on the quality of organic matter, soil enzyme activity, and soil microbial community (Kraus et al. 2003; Smolander et al. 2012). For example, condensed tannins in soil can form recalcitrant complexes with proteins due to the presence of many hydroxyl functional groups in their molecular structure (Kraus et al. 2003). Further, soil microbial activity can be directly affected by the toxicity of condensed tannins or by the complexation and inactivation of the extracellular enzymes driving mineralization processes (Scalbert 1991). In practice, studies have indicated that condensed tannins often reduce the rates of carbon and/or nitrogen mineralization (Kraal et al. 2009; Schimel et al. 1998; Fierer et al. 2001; Kanerva et al. 2006).

Evidence suggests that condensed tannins in the leaf tissues of plants have a large effect not only on soil mineralization processes but also on subsequent plant nutrient acquisition and nutrient cycling in an ecosystem (Wurzburger and Hendrick 2009; Ushio et al. 2009; Northup et al. 1995). Therefore, condensed tannins have been recently highlighted as key substances in regulating the feedbacks between plants and soil. Moreover, studies have also suggested that plant-soil feedbacks are a potential driver of plant community assemblage and ecosystem processes (Wardle et al. 2004), such as 
67 plant species coexistence (Frelich et al. 1993; Miki et al. 2010), nutrient cycling (Hobbie 1992), and plant community succession (Kardol et al. 2007; van der Putten et al. 2009). Therefore, an understanding of the influence of tannins on soil mineralization processes can provide insights into tannin regulation mechanisms of the ecosystem processes through their influence on plant-soil feedbacks.

The control of tannins on soil processes has been previously studied (Bowman et al. 2004; Fierer et al. 2001; Meier and Bowman 2008; Schimel et al. 1998; Kanerva et al. 2006; Kraal et al. 2009; Nierop et al. 2006). For example, Fierer et al. (2001) extracted four fractions (i.e., four molecular weight categories) of poplar (Populus balsamifera) condensed tannins and examined the effects of the tannin fractions on soil nitrogen cycling by incubation experiments. The addition of tannins reduced the nitrogen availability, although the exact mechanism differed depending on the molecular weight of the added tannins. Low-molecular-weight tannins generally served as a labile carbon source and stimulated microbial immobilization of nitrogen, whereas high-molecular-weight tannins appeared to inhibit degrading enzymatic activities by forming a recalcitrant complex with both the enzymes and their substrates. In addition, as suggested by Kanerva et al. (2006) and Kanerva and Smolander (2008), the low-molecular weight fractions probably contained compounds other than tannins such as waxes, chlorophyll and terpenoids, which can also contributes to the differences in soil responses to tannin addition between fractions. Although their experiments under laboratory conditions provide insights into the role of condensed tannins in nutrient cycling (Bowman et al. 2004; Fierer et al. 2001; Kanerva et al. 2006), the detailed mechanism of tannin-based regulation of soil mineralization processes is not fully 
understood. This limitation is attributable to the lack of studies exploring the effect of tannins on the soil microbial community despite the finding that the composition and abundance of the soil microbial community fundamentally drives soil mineralization processes (Strickland et al. 2009; Balser and Firestone 2005).

The effects of tannins depend on differences in microbial abilities to resist tannin toxicity and the ability to utilize condensed tannins (Kraus et al. 2003; Scalbert 1991). Some groups of microbes (e.g., a group of saprophytic fungi) can utilize and grow on media containing a high concentration of condensed tannins. Furthermore, for fungi, the minimum inhibitory concentration of tannins is often higher than $0.5 \mathrm{~g} \mathrm{l}^{-1}$ in a medium, but the value is generally lower in bacteria (Scalbert 1991 and references therein). Thus, a specific concentration of condensed tannins can result in selection for a specific group of microbes, altering the composition of the soil microbial communities. Further, the effects of condensed tannins on soil processes under field conditions with many influential factors have not been investigated, affecting our understanding of the mechanism by which tannins influence the soil microbial communities and soil processes.

A tropical montane forest on Mt. Kinabalu, Borneo, Malaysia, provides an opportunity to test the potential effects of condensed tannins on the soil microbial community and mineralization processes. The variations in leaf chemistry (e.g., the concentration of condensed tannins) of locally coexisting plants in the forest are likely to induce distinct spatial patchiness of the soil physicochemical and microbial properties. Indeed, our previous studies found that the composition and activities of the soil microbial community were different beneath different tree species, and the difference 
113 was distinct especially between a dominant conifer, Dacrydium gracilis (Podocarpaceae)

114 and a dominant broadleaf, Lithocarpus clementianus (Fagaceae) (Ushio et al. 2008;

115 Ushio et al. 2010b). Specifically, saprophytic fungi were more dominant beneath the

116 conifer species than beneath the broadleaf species. The spatial pattern of microbial

117 properties corresponds well to the concentration gradient of condensed tannins in soil

118 (e.g. fungi-to-bacteria ratio positively corresponds to the concentration of condensed

119 tannins in soil; Ushio et al. 2010b), suggesting that condensed tannins are one of the

120 factors responsible for these tree-specific spatial patterns. Moreover, as the nitrogen

121 mineralization rate is constantly low in this forest (Kitayama et al. 2004a; Kitayama et al.

122 1998; Hall et al. 2004), it is also likely that the effect of tannins on the nitrogen

123 mineralization rate influences subsequent plant nutrient acquisition.

124 In the tropical montane forest, tannin-addition experiments were conducted under

125 both field and laboratory conditions to evaluate the effects of condensed tannins on soil

126 mineralization processes and microbial communities. Our specific hypotheses are as

127 follows: 1) the addition of condensed tannins will inhibit general microbial activities

128 (i.e., soil enzyme activity, respiration rate, and nitrogen mineralization rate) by their

129 protein-precipitation capacity; 2) the addition of condensed tannins will result in an

130 increase in fungal dominance because of their utilization advantage for condensed

131 tannins compared with the bacterial community; and 3) under Dacrydium the initial

132 dominance of fungi will result in a lower effect of tannin addition due to greater fungal

133 ability to degrade the added tannins. 
135

136

137

138

139

140

141

142

143

144

145

146

147

148

149

150

151

152

153

154

155

156

157

\section{Materials and methods}

Site description and selected tree species

Soils for the experiment were collected from a permanent plot in a primary montane forest on the south slope of Mt. Kinabalu in Sabah, Borneo, Malaysia (summit height = $\left.4095 \mathrm{~m} ; 6^{\circ} 05^{\prime} \mathrm{N}, 116^{\circ} 33^{\prime} \mathrm{E}\right)$; the tannin-addition experiment was conducted in this plot and also under controlled laboratory conditions. The study was conducted from January to March 2008. The research plot is located at $1560 \mathrm{~m}$ above sea level, near the headquarters of the Kinabalu Park. The climate is humid and tropical with a mean annual air temperature of $18^{\circ} \mathrm{C}$ and annual precipitation of $2714 \mathrm{~mm}$ (Aiba and

Kitayama 1999). This area does not have marked seasonality but shows slight variation in the monthly precipitation. The plot is covered with evergreen broadleaf trees interspersed with conifers (relative basal area of conifers 15\%), including 109 tree species per hectare with diameter $>10 \mathrm{~cm}$ at breast height (Aiba et al. 2002). The decomposition rate of standing litter is low compared with that at lowland sites because of the relatively low temperature. Thus organic soil horizon in this plot is thick (ca. 5 $\mathrm{cm}$ ), and the soil is acidic ( $\mathrm{pH}$ measured in water is $\sim 4.0$ ). The plot is in the last stage of pedogenesis, and the soil contains a low concentration of phosphorus, which is thought to limit plant growth (Kitayama et al. 2004a). Moreover, the measurement of net nitrogen mineralization rate in topsoils $(0-15 \mathrm{~cm}$ depth) of this forest revealed that the mineralization rate was nearly zero, or often negative over a year, indicating that plant performance can also be limited by the nitrogen availability (Hall et al. 2004; Kitayama 
158

159

160

161

162

163

164

165

166

167

168

169

170

171

172

173

174

175

176

177

178

179

180

et al. 2004a; Kitayama et al. 1998). In this forested area, two dominant tree species were selected: Dacrydium gracilis (Podocarpaceae; conifer) and Lithocarpus clementianus

(Fagaceae; broadleaf tree). This is because the leaf chemistry of these species is markedly different, especially with regard to the concentration of condensed tannins (Dacrydium, 6.38\%; Lithocarpus, 0\%; Suzuki, S. unpublished data), and because the soil microbial and physicochemical properties are also different beneath the two species (Table S1, Ushio et al. 2008; Ushio et al. 2010b).

\section{Tannin extraction}

Condensed tannins were prepared as described by Fierer et al. (2001) with the following modifications. Fresh leaves of Dacrydium were collected from tree individuals growing in this forested area, and the leaves were immediately taken back to the laboratory. The leaves were freeze-dried (yielded $\sim 150 \mathrm{~g}$ of dried leaves), finely ground and rinsed three times with n-hexane, following which n-hexane was discarded. The remaining leaf material was extracted three times with $70 \%$ acetone, and the three extracts were combined and concentrated by evaporation with a vacuum pump (DIVAC 0.6 L; Tokyo Rikakikai Co. Ltd., Tokyo, Japan). The concentrated extract was fractionated six times with $100 \%$ ethyl acetate, after which the ethyl acetate (hydrophobic) fraction containing low-molecular-weight phenolics was discarded. This is because the fraction appeared to influence the soil processes in a very different manner when compared with high-molecular-weight phenolics such as condensed tannins, and because this fraction contains a minor fraction of tannins (Fierer et al. 2001; Kanerva et al. 2006). The 
181 remaining $70 \%$ acetone fraction was concentrated by freeze-drying and loaded onto a

182 Sephadex LH-20 (GE Healthcare, UK, Ltd., England) chromatography column (gel

183 length $=32 \mathrm{~cm}$, flow rate $\approx 1.5 \mathrm{ml} \mathrm{min}^{-1}$ ). The column was eluted with $50 \%$ methanol

184 followed by $70 \%$ acetone. The acetone fraction was then collected and concentrated by

185 evaporation followed by freeze-drying. This fraction was thought to contain

186 high-molecular-weight tannins (Fierer et al. 2001; Kanerva et al. 2006). Extraction of

187 approximately $150 \mathrm{~g}$ Dacrydium leaves yielded $8.5 \mathrm{~g}$ of condensed tannins $(5.46 \%$ of the

188 initial dry weight). This value is reasonable in comparison with the quantification value

189 of condensed tannins (6.38\%; Suzuki S. unpublished data) with the acid-butanol method

190 (Porter et al. 1986).

191

192 Tannin-addition experiment under field conditions

193

194 Five replicate individuals of the Dacrydium and Lithocarpus were selected in the forest

195 plot. Two soil collars (diameter $\times$ height; $10 \mathrm{~cm} \times 10 \mathrm{~cm}$ ) were buried beneath each tree

196 crown of the selected individuals for two weeks before the tannin-addition experiment.

197 One collar was for tannin addition-treatment, and the other one was for control

198 (deionized water-addition treatment). Most fine roots inside these collars were separated

199 from plant individuals by soil collar insertion, but possible effects of deeper roots could 200 not be excluded in this study. Organic matter inputs from the excised roots may hamper

201 effects of condensed tannins on soil processes, but the organic matter, especially for

202 labile fractions, can be consumed during the two-weeks stabilization. After the

203 two-weeks stabilization, $350 \mathrm{mg}$ of condensed tannins per soil collar in deionized water 
204 was added for the tannin treatment, resulting in approximately 20 - to 30 -fold higher than 205 the concentration of condensed tannins in intact soil (Ushio et al. 2010b). Only the soil

206 respiration rate was monitored one week after the addition of condensed tannins to avoid

207 destructive soil sampling for the other analyses. The soil samples inside the soil collars

208 were collected after one week of monitoring, and their $\mathrm{pH}$, enzyme activity, and

209 microbial community (lipid profile) were analyzed.

211 Laboratory incubation experiments

213 Five replicates of the two tree species were selected, and soil samples for the laboratory 214 incubation experiment were collected from the surface organic soil layer $(c a .0-5 \mathrm{~cm}$ 215 depth) beneath these individuals. Before applying them to the incubation experiments, 216 the soils were maintained at $20^{\circ} \mathrm{C}$ in the dark with a constant moisture condition for a 217 week to stabilize the soil conditions. Each soil sample was divided for two treatments: 218 control (i.e., deionized water-addition treatment) and condensed tannin-addition 219 treatment. Approximately $60 \mathrm{~g}$ of each fresh soil sample was used for this experiment. 220 Extracted high-molecular-weight condensed tannins were added in soluble form 221 in deionized water to the five soil samples of both tree species at the equivalent of $10 \mathrm{mg}$ 222 condensed tannins per gram dry soil, resulting in concentrations of approximately equal to 20- to 30-fold higher than the concentration of condensed tannins in intact soil. After

224 the addition, a subset of each replicate soil sample was sampled along the time course of $2251,3,7,14$, and 21 days. Therefore, 100 soil samples (two tree species $\times$ two treatments $\times$ 226 five replicates $\times$ five sampling days) were obtained totally. 
228 Soil physicochemical and microbial properties

230 The soil $\mathrm{pH}$, respiration rate, enzyme activity, and microbial community (lipid profile) in

231 each sample were analyzed. The properties of the intact soil samples (i.e., before the

232 samples were divided for the treatments) were also analyzed (see Table S1). The soil pH

233 in water and $0.01 \mathrm{~N} \mathrm{KCl}$ was measured with soil-to-solution ratios of 1:5 and 1:10,

234 respectively. The soil respiration rate was measured with a photosynthesis instrument

236 chamber, which was then directly fitted to a half-buried soil collar to measure the

237 respiration rate under field conditions. In the case of the laboratory incubation

238 experiment, incubated soil was placed in a column-shaped box, and its respiration rate

239 was directly measured with the same system. Another set of soil samples (i.e., two tree

240 species $\times$ two treatment $\times$ five replicates) was prepared for nitrogen mineralization

241 experiment. Net nitrogen mineralization rates were determined by comparing the initial

242 concentration of inorganic nitrogen (i.e., ammonium + nitrate) with the final

243 concentration of inorganic nitrogen after two weeks of incubation at $20^{\circ} \mathrm{C}$ in the dark

244 with a constant moisture condition. The concentration of inorganic nitrogen was

245 measured colourimetrically (FUTURA; Alliance).

246 For the soil enzyme analyses, the potential activities of acid phosphatase,

$247 \quad \beta$-D-glucosidase, $N$-acetylglucosaminidase, phenol oxidase, and peroxidase were

248 measured. The soil samples were maintained in a refrigerator at $4^{\circ} \mathrm{C}$ for up to three days

249 before the enzyme activities were measured. For acid phosphatase, $\beta$-D-glucosidase, and 
$250 \quad N$-acetylglucosaminidase analyses the modified method of Tabatabai and Bremer (1969)

251 was used. A standard curve was developed using $p$-nitrophenol. For phenol oxidase and

252 peroxidase, 3,4-dihydroxy-L-phenylalanine (DOPA) was used as substrate, and a

253 standard curve was developed using DOPA and tryrosinase. The detailed method was

254 described in our previous studies (Ushio et al. 2010a; Ushio et al. 2010b).

For the analysis of microbial lipid biomarkers (White and Ringelberg 1998),

256 each of soil samples was well mixed, frozen, and then freeze-dried immediately after

257 soil sampling. We extracted, purified and identified PLFAs from microbial cell

membranes using a hybrid lipid extraction based on a modified Bligh and Dyer (1959)

259 technique, combined with fatty acid methyl ester analysis (FAME) as described by

260 Microbial ID Inc. (Hayward, CA). The detailed method was described in Ushio et al

261 (2010b). Total lipid abundance was calculated as a sum of lipids of which chain length

262 was from 10 to 20. Indicator lipids used for calculation were as follows. Total bacterial

263 biomass was estimated by the sum of the abundance of $i 14: 0,15: 0, i 15: 0, a 15: 0, i 16: 0$,

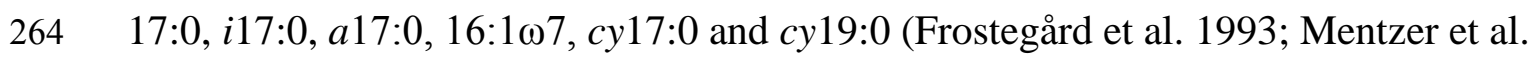

265 2006). Gram-positive bacteria were represented by the branched lipids including $i 14: 0$,

$266 \quad i 15: 0, a 15: 0, i 16: 0, i 17: 0$, and $a 17: 0$ (Zelles et al. 1995), whereas Gram-negative

267 bacteria were represented by the mono-saturated and cyclopropyl lipids including

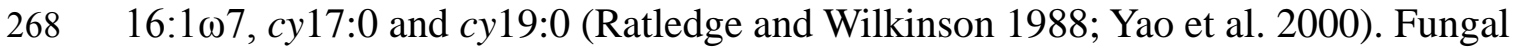

269 biomass was estimated by the abundance of 18:2 $\omega 6,9$ (Frostegård et al. 1993).

270 Fungi-to-bacteria ratio and Gram-positive bacteria to Gram-negative ratio were

271 calculated as 18:2 $\omega 6,9 /$ (sum of all bacterial lipid), and (sum of the branched lipids)/(sum

272 of the mono-unsaturated and cyclopropyl lipids), respectively. 
274 Statistics

276 Effects of condensed tannins, tree species and incubation time in the laboratory

277 incubation experiment were tested by additive mixed models (Wood 2004) since it was

278 likely that the effects of incubation time on the soil properties were not linear

279 (smoothing function was applied for the effect of incubation time) and because we did

280 not have a priori hypothesis about the relationship between incubation time and the soil

281 properties. Model formulation for the field experiment was as follows: explained

282 variable $=$ tree species + treatment + treatment $\times$ tree species + random effect of each

283 soil sample. Model formulation for the laboratory incubation experiment was as follows:

284 explained variable $=$ tree species + treatment + treatment $\times$ tree species + days after

285 tannin addition + random effects of each soil sample. Effects of condensed tannins and

286 tree species in the field experiment were tested by linear mixed models. Statistical

287 analyses for the field tannin-addition experiment were conducted only on the data

288 obtained after tannin addition. Principal component analysis (PCA) was performed for

289 the lipid data to evaluate the overall composition of the microbial communities. Before

290 conducting this analysis, the values of the concentrations of indicative lipids were

291 divided by the total lipid abundance for evaluating the relative abundance of each lipid

292 biomarker. To ensure normality in the lipid data set, the values were transformed by

293 considering the negative arcsine of the square root of mole percent (Balser and Firestone

294 2005). The 'mgcv' (Wood 2004) and 'nlme' (Pinheiro et al. 2009) packages were used

295 for the additive mixed model analysis and linear mixed model analysis, respectively. All 
296 statistical analyses were conducted by using the free statistical environment R ( R

297 Development Core Team 2011). In the analyses, $P<0.05$ was regarded as significant. In

298 addition, $0.05<P<0.1$ was regarded as marginally significant, considering the inherent

299 spatial heterogeneity of the soil properties in surface organic layer.

300 
301

302

303

304

305

306

307

308

309

310

311

312

313

314

315 Tannin-addition experiments under field conditions

\section{Results}

Intact soil properties tree species (Ushio et al. 2008; Ushio et al. 2010b).

Properties of intact soils differed beneath each tree species, Dacrydium and Lithocarpus (Table S1). A higher concentration of condensed tannins and a higher fungi-to-bacteria ratio were measured in the soils beneath the Dacrydium than in those beneath the Lithocarpus. Lower water-extracted soil $\mathrm{pH}$, lower activity of $\mathrm{N}$-acetylglucosaminidase, lower nitrogen mineralization rate, and lower rate of soil respiration were detected in the soils beneath the Dacrydium. On the other hand, no significant differences were observed in the other soil properties. These trends were generally consistent with those of the spatial pattern of soil physicochemical and microbial properties underneath these

317 The activities of acid phosphatase, $\beta$-D-glucosidase, and $N$-acetylglucosaminidase were

318 significantly influenced by the tannin addition (Table 1). Mean values of the three 319 enzyme activities were lower after the tannin-addition treatment than the control 320 treatment, and the effects were similar in the cases of both the Dacrydium and the 321 Lithocarpus soil samples (Fig. 1a-c). A marginally significant effect of the interaction 322 between tree and tannins was found on the phenol oxidase activity: the activity after 323 tannin addition was lower than that after the control treatment in the Dacrydium soil 
324 samples, but this was not the case for the Lithocarpus soil samples (Fig. 1d). There were 325 no significant effects of the interaction of tree $\times$ tannins on the soil enzyme activities and 326 respiration rate except for phenol oxidase, indicating that condensed tannins had similar 327 effects on these parameters (except for the phenol oxidase activity) in both the 328 Dacrydium and the Lithocarpus soil samples. In general, tannin addition also had a 329 significant inhibition effect on the soil respiration rate (Table 1). Specifically, the 330 respiration rate was lower from $3.5 \mathrm{~h}$ to $7 \mathrm{~d}$ in the tannin-treated soils (Fig. 2). A 331 significant tree $\times$ tannin interaction effect was found on the water-extracted soil $\mathrm{pH}$ 332 (Table 1).

The addition of condensed tannins did not significantly influence total lipid 334 abundance, fungi-to-bacteria ratio, or gram-positive bacteria to gram-negative bacteria 335 ratio (Table 1). PCA revealed the response of the overall composition of the microbial 336 community to the addition of condensed tannins. Here, only the first three principal 337 components (PCs) are reported: PC1, PC2, and PC3 explained 40.6\%, 18.2\%, and 10.5\%

338 of the total variation, respectively. The addition of condensed tannins did not

339 significantly influence any of the PCs (Table 1). Weak effects of the interaction between 340 tree and tannins on the gram-positive bacteria to gram-negative bacteria ratio were 341 observed. Tree species had significant and strong effects on the fungi-to-bacteria ratio 342 and a part of the overall microbial composition (Table 1), which is consistent with the 343 results of the previous studies (Ushio et al. 2008; Ushio et al. 2010b).

345 Laboratory incubation experiment 
347 The addition of condensed tannins significantly influenced the activity of phenol oxidase 348 (Table 2): the activity after the tannin-addition treatment was significantly lower than 349 that after the control treatment, and this trend was true for both Dacrydium and 350 Lithocarpus soil samples (Figs. 3d and 4d). No significant effects of tannin addition on 351 other soil enzyme activities were detected. A significant effect of the interaction of tree $\times$ 352 treatment was found on the activity of peroxidase (Table 2). The activity of peroxidase 353 after the tannin-addition treatment was higher than after the control treatment in the case 354 of the Lithocoarpus soil samples during 1-14 d, but was almost the same in the case of 355 the Dacrydium soil samples irrespective of the treatment (Figs. 3e and 4e). Soil 356 respiration rate was not influenced by the addition of condensed tannins (Table 2).

357 However, soil respiration rate after the tannin-addition treatment was slightly lower than 358 those after the control treatment for 3-21 d (Figs. 3f and 4f), which resulted in a 359 marginally significant effect of tannin-addition on cumulative carbon dioxide emission 360 (Table 2 and Fig. S1). Tree $\times$ treatment interaction effects were found in the case of 361 cumulative carbon dioxide.

362 The fungi-to-bacteria ratio was significantly higher after the tannin-addition 363 treatment than the control treatment (Table 2 and Fig. 5). The mean concentration of the 364 primary fungal biomarker lipid $(18: 2 \omega 6,9)$ was slightly higher after the tannin-addition 365 treatment, whereas the mean concentration of the sum of bacterial lipids was lower after 366 the addition of condensed tannins though the differences were not significant (data not 367 shown). No significant change was found in the total lipid abundance by tannin addition 368 (Table 2). Further, the gram-positive bacteria to gram-negative bacteria ratio was 369 marginally significantly higher after the tannin-addition treatment (Table 2). PCA 
370 revealed overall microbial community compositional response to the addition of

371 condensed tannins. Here, only the first three PCs are reported. PC1, PC2, and PC3

372 explained $39.8 \%, 21.8 \%$, and $9.5 \%$ of the total variation, respectively. The addition of

373 condensed tannins influenced PC2 significantly, but PC1 and PC3 were not influenced

374 (Table 2). No significant effects of the interaction between tree and treatment were

375 observed on soil microbial properties.

376 The net nitrogen mineralization rate was significantly lower in the soils beneath

377 the Dacrydium (Fig. 6). The addition of condensed tannins decreased net nitrogen

378 mineralization rate in the Lithocarpus soil samples, but not significantly in the

379 Dacrydium soil samples. The KCl-extracted soil pH was slightly but significantly lower

380 after the tannin-addition treatment than the control treatment (Table 2).

381 


\section{Discussion}

\section{Effects of tannin-addition on soil microbial activities}

The first hypothesis, the addition of condensed tannins will inhibit microbial activities, was generally supported by the field and laboratory experiments. We found that tannin addition significantly lowered the activities of acid phosphatase, $\beta$-D-glucosidase and $\mathrm{N}$-acetylglucosaminidase in the field experiment as well as phenol oxidase activity in the laboratory incubation experiment (Table 1 and 2). Condensed tannins have the ability to form a recalcitrant protein-tannin complex (Kraus et al. 2003), which can inhibit soil enzyme activity; thus, the lower enzyme activities could be due to precipitation of the enzymes with tannins. The soil respiration rate after tannin treatment was significantly lower from $3.5 \mathrm{~h}$ to $7 \mathrm{~d}$ in the field experiments (Fig. 2). In addition, cumulative carbon dioxide emission was significantly lower after tannin treatment in the laboratory experiment (Table 2 and Fig. S1). These results are in agreement with the previous studies (Fierer et al. 2001; Schimel et al. 1998). Reduction of soil respiration could be due to either the inhibitory effects of tannins on the carbon-degrading enzyme activity (i.e., $\beta$-D-glucosidase and phenol oxidase) or their direct toxicity to soil microbes (Kraus et al. 2003; Smolander et al. 2012; Scalbert 1991).

On the contrary to the above-mentioned enzymes, no significant inhibitory effects of condensed tannins on the other soil enzyme activities were found (Table 1 and 2). The inhibitory effects of condensed tannins on enzymes may differ depending on the chemical characteristics of the enzyme species (Kraus et al. 2003). In addition, it is 
405 interesting that the inhibitory effect of tannin addition on the enzyme activities (i.e. acid 406 phosphatase and $\beta$-D-glucosidase) found in the field experiment was not detected in the 407 laboratory experiment. Under field conditions, external substrates are continuously 408 supplied to soil from leaf litter and throughfall, which may contribute to the slightly 409 higher activities of enzymes than under laboratory condition (Figs. 1, 3 and 4). The 410 higher microbial activity in the control treatment may render the inhibiting effect of 411 condensed tannins clearer under field conditions than under laboratory conditions. 412 Reduction of nitrogen mineralization rate by condensed tannins was observed in 413 the Lithocarpus soils in this study (Fig. 6) as well as in previous studies (Fierer et al.

414 2001; Schimel et al. 1998). The tannin-protein complex is recalcitrant, and is generally 415 difficult for soil microbes to degrade (Majuakim 2005; Kraus et al. 2003). Therefore, the 416 mineralization pathway from protein to inorganic nitrogen is often inhibited.

417 Precipitation can also inhibit the activity of nitrogen-degrading enzymes (Kraus et al. 418 2003, and references therein), and consequently inhibit nitrogen mineralization.

419 However, the activity of $\mathrm{N}$-acethylglucosaminidase (one of the nitrogen-degrading 420 enzymes) was not significantly lower after tannin addition (Table 2). Therefore, the 421 reduction of the nitrogen mineralization rate observed in the Lithocarpus soil samples 422 appears to be primarily due to the formation of recalcitrant tannin-protein complex with 423 their protein substrate. In addition, toxic effects of the tannins on soil microbes may 424 contribute to the reduction of the nitrogen mineralization rate (Kraus et al. 2003). It is 425 possible, however, that condensed tannins might have an inhibitory effect on the 426 activities of nitrogen-degrading enzymes that were not examined in this study. 
428 Lithocarpus soils, no significant decrease in the net nitrogen mineralization rate was 429 found in the tannin-treated Dacrydium soil samples versus controls (Fig. 4). The net 430 nitrogen mineralization rate in the Dacrydium soil samples may be lower due to the 431 relatively high background concentration of condensed tannins, and thus, further 432 addition of condensed tannins to these samples may not reduce the nitrogen 433 mineralization rate. This result partly supports our third hypothesis that effects of tannins 434 will be less significant under Dacrydium than under Lithocarpus. We note that the values 435 of the net nitrogen mineralization rate were considerably higher than those reported in 436 the studies previously conducted at this site (Kitayama et al. 1998; Kitayama et al. 437 2004a). One possible reason for this difference is the difference in the soil sampling 438 depth (i.e., surface organic soils [ $\mathrm{ca} .0-5 \mathrm{~cm}$ depth] versus deeper mineral soils [0-15 $\mathrm{cm}$

439 depth]), sampling place (sampling places in the forest were not exactly the same among 440 the studies) and/or methodological differences (e.g., laboratory incubation versus the 441 buried bag method). Both soil depth and incubation methodology can significantly 442 influence the values of inorganic nitrogen concentration (Piccolo et al. 1994; Neill et al. 443 1997).

445 Effects of tannin-addition on the composition of the soil microbial community

447 The second hypothesis, the addition of condensed tannins will result in an increase in 448 fungal dominance, was also supported by the laboratory incubation experiments. Tannin 449 addition had significant effects on the composition of the soil microbial community in 450 the laboratory incubation experiment (Table 2). Specifically, the fungi-to-bacteria ratio 
451 after tannin-addition was higher than that in the control treatment (Fig. 5), due to the

452 higher concentration of a saprophytic fungal biomarker lipid and the slightly lower

453 concentration of bacterial biomarker lipids after the tannin-addition treatment (data not

454 shown). Although cautions are needed to interpret the lipid data (see Frostegârd et al.

455 2011), the concentration of a lipid biomarker is still an good estimate of microbial

456 biomass (White et al. 1979; Frostegård et al. 1991). Thus we conclude that tannin

457 addition may result in an increase in saprophytic fungal biomass in the laboratory

458 experiment. The saprophytic fungal community can often utilize condensed tannins as

459 their energy source more effectively than the bacterial community, and can be more

460 tolerant to the toxicity of condensed tannins (Scalbert 1991). These properties of the

461 fungal community may be advantageous in soils with the tannin addition, and may

462 consequently result in a higher fungi-to-bacteria ratio. In addition, at least a portion of

463 the overall composition of the microbial community can be altered by tannin addition,

464 based on the significant tannin-effect on the PC2 (Table 2). No significant tree $\times$ tannin

465 interaction effects on the properties of the soil microbial community (Table 2) suggested

466 that condensed tannins influenced the composition of the microbial community in a

467 similar manner in both the Dacrydium and the Lithocarpus soils under the laboratory

468 condition.

469 Although tannin addition had a significant effect on the fungi-to-bacteria ratio in

470 the laboratory experiment, no significant changes were found in this ratio in the field

471 experiment (Table 1). Additionally, in terms of the overall composition of the microbial

472 community, PCs were unchanged (Table 1). Therefore, tannins had very weak or no

473 effects on the composition of the soil microbial community in the field experiment. One 
474 reason for the different results between the laboratory experiment and the field

475

476

477

478

479

480

481

482

483

484

485

486

487

488

489

490

491

492

493

494

experiment could be that a portion of the condensed tannins may have leached into

deeper soil layers or was flushed by rainfall (rainfall event occurred three times during

the course of the one-week tannin-addition experiment under field conditions), weakening their influence.

Implications for plant-soil feedbacks in the tropical montane forest

Based on our results, we suggest that a higher concentration of condensed tannins in leaf tissues of the Dacrydium than those of the Lithocarpus could be one of the factors inhibiting the carbon and nitrogen mineralization process in the soil beneath tree crowns of Dacrydium. Since nitrogen availability is thought to limit plant productivity in this weathered tropical montane forest (Kitayama et al. 2004b), condensed tannins can have significant influences on performance of plants (e.g. nitrogen acquisition and/or growth rate of plants) through their effects on nitrogen mineralization process, as already suggested by our theoretical study (Ushio et al. 2009). For example, plants growing on soil beneath Dacrydium might have lower growth rates than those beneath Lithocaprus because of the lower nitrogen availability. Also, the tannin-induced feedback effects might depend on plant nitrogen acquisition strategy such as mycorrhizal fungal association, but such studies are still lacking. Therefore, future studies should focus on the performance of the plants growing on the soil beneath the tree crowns of the two species as well as mycorrhizal fungal associations. Because the conifers (Podocarpaceae) are a unique component of tropical montane forests (Kitayama et al. 
497 2011), and because plant-soil feedbacks are an important driver to regulate forest

498 ecosystem dynamics (Wardle et al. 2004), such studies on the plant-soil feedbacks will

499 improve our understanding of the dynamics of tropical montane forest ecosystems. 
502 We thank Prof. Tohru Mitsunaga and Dr. Hiroyuki Takemoto for their support with the

503 tannin extraction procedure. We also thank staffs of the Sabah Parks for their support

504 and permission throughout the course of our research and Dr. Sizuo Suzuki for providing

505 us with the data on leaf phenolics. We also thank Dr. Harry Read, Mr. Kevin Budsberg,

506 Dr. Chao Liang and members of the Balser Lab at the University of Wisconsin-Madison

507 for their support with lipid analysis. This research was supported by a grant-in-aid

508 (MESSC 19380010) to K.K. and in part by Global COE program A06 to Kyoto

509 University. M.U. is supported by a Japan Society for the Promotion of Science Research

510 Fellowship for Young Scientists (21-1526 and 23-586).

511 


\section{References}

Aiba S, Kitayama K (1999) Structure, composition and species diversity in an altitude-substrate matrix of rain forest tree communities on Mount Kinabalu, Borneo. Plant Ecol 140:139-157

Aiba S, Kitayama K, Rebin R (2002) Species composition and species-area relationships of trees in nine permanent plots in altitudinal sequences on different geological substrates of Mount Kinabalu. Sabah Parks Nature Journal 5:7-69

Balser TC, Firestone MK (2005) Linking microbial community composition and soil processes in a California annual grassland and mixed-conifer forest. Biogeochemistry 73:395-415

Bligh EG, Dyer WJ (1959) A rapid method of total lipid extraction and purification. Can J Biochem Physiol 37:911-917

Bowman WD, Steltzer H, Rosenstiel TN, Cleveland CC, Meier CL (2004) Litter effects of two co-occurring alpine species on plant growth, microbial activity and immobilization of nitrogen. Oikos 104:336-344

Fierer N, Schimel JP, Cates RG, Zou J (2001) Influence of balsam poplar tannin fractions on carbon and nitrogen dynamics in Alaskan taiga floodplain soils. Soil Biol Biochem 33:1827-1839

Frelich LE, Calcote RR, Davis MB, Pastor J (1993) Patch formation and maintenance in an old-growth hemlock-hardwood forest. Ecology 74:513-527

Frostegård A, Bååth E, Tunlid A (1993) Shifts in the structure of soil microbial communities in limed forests as revealed by phospholipid fatty acid analysis. 
Soil Biol Biochem 25:723-730

536

Frostegârd A, Tunlid A, Bââth E (2011) Use and misuse of PLFA measurements in soils. Soil Biol Biochem 43:1621-1625

Frostegård A, Tunlid A, Bååth E (1991) Microbial biomass measured as total lipid phosphate in soils of different organic content. J Microbiol Methods 14:151-163

Hall SJ, Asner GP, Kitayama K (2004) Substrate, climate, and land use controls over soil $\mathrm{N}$ dynamics and $\mathrm{N}$-oxide emissions in Borneo. Biogeochemistry 70:27-58

Hartley SE, Jones CG (1997) Plant chemistry and herbivory: or why the world is green. Plant ecology, 2nd edition edn. Blackwell Science, Cambridge, Mass

Hobbie SE (1992) Effects of plant species on nutrient cycling. TREE 7:336-339

Kanerva S, Kitunen V, Kiikkilä O, Loponen J, Smolander A (2006) Response of soil C and $\mathrm{N}$ transformations to tannin fractions originating from Scots pine and Norway spruce needles. Soil Biol Biochem 38:1364-1374

Kanerva S, Smolander A (2008) How do coniferous needle tannins influence C and N transformations in birch humus layer? Eur J Soil Biol 44:1-9

Kardol P, Cornips NJ, van Kempen MML, Bakx-Schotman JMT, van der Putten WH (2007) Microbe-mediated plant-soil feedback causes historical contingency effects in plant community assembly. Ecol Monogr 77:147-162

Kitayama K, Aiba S, Takyu M, Majalap N, Wagai R (2004a) Soil phosphorus fractionation and phosphorus-use efficiency of a Bornean tropical montane rain forest during soil aging with podozolization. Ecosystems 7:259-274

Kitayama K, Aiba S, Ushio M, Seino T, Fujiki Y (2011) The ecology of porocarps in tropical montane forests of Borneo: distribution, population dynamics, and soil 
558

559

560

561

562

563

564

565

566

567

568

569

570

571

572

573

574

575

576

577

578

579

580

nutrient acquisition. In: Turner BL, Cernusak LA (eds) Ecology of the Podocarpaceae in Tropical Forests, vol 95. Smithsonian Contributions to Botany. Smithsonian Institution Scholarly Press, Washington D. C., pp 101-117

Kitayama K, Aiba SI, Majalap-Lee N, Ohsawa M (1998) Soil nitrogen mineralization rates of rainforests in a matrix of elevations and geological substrates on Mount Kinabalu, Borneo. Ecol Res 13:301-312

Kitayama K, Suzuki S, Hori M, Takyu M, Aiba SI, Majalap-Lee N, Kikuzawa K (2004b) On the relationships between leaf-litter lignin and net primary productivity in tropical rain forests. Oecologia 140:335-339

Kraal P, Nierop KGJ, Kaal J, Tietema A (2009) Carbon respiration and nitrogen dynamics in Corsican pine litter amended with aluminium and tannins. Soil Biol Biochem 41:2318-2327

Kraus TEC, Dahlgren RA, Zasoski RJ (2003) Tannins in nutrient dynamics of forest ecosystems - A review. Plant Soil 256:41-66

Kuiters AT (1990) Role of phenolic substances from decomposing forest litter in plant-soil interactions. Acta Bot Neerl 39:329-348

Majuakim L (2005) Influence of foliar polyphenols on dissolved organic nitrogen in the soil water of the tropical montane forests on Mount Kinabalu, Borneo. Master Thesis, Kyoto University, Japan

Meier CL, Bowman WD (2008) Phenolic-rich leaf carbon fractions differentially influence microbial respiration and plant growth. Oecologia 158:95-107

Mentzer JL, Goodman RM, Balser TC (2006) Microbial response over time to hydrologic and fertilization treatments in a simulated wet prairie. Plant Soil 
581

582

583

584

585

586

587

588

589

590

591

592

593

594

595

596

597

598

599

600

601

602

603

284:85-100

Miki T, Ushio M, Fukui S, Kondoh M (2010) Functional diversity of microbial decomposers facilitates plant coexistence in a model of plant-microbe-soil feedback. Proc Natl Acad Sci U S A 107:14251-14256

Neill C, Piccolo MC, Cerri CC, Steudler PA, Melillo JM, Brito M (1997) Net nitrogen mineralization and net nitrification rates in soils following deforestation for pasture across the southwestern Brazilian Amazon Basin landscape. Oecologia $110: 243-252$

Nierop KGJ, Verstraten JM, Tietema A, Westerveld JW, Wartenbergh PE (2006) Shortand long-term tannin induced carbon, nitrogen and phosphorus dynamics in Corsican pine litter. Biogeochemistry 79:275-296

Northup RR, Yu Z, Dahlren RA, Vogt KA (1995) Polyphenol control of nitrogen release from pine litter. Nature 377:227-229

Piccolo MC, Neill C, Cerri CC (1994) Net nitrogen mineralization and net nitrification along a tropical forest-to-pasture chronosequence. Plant Soil 162:61-70

Pinheiro J, Bates D, DebRoy S, Sarkar D, R Development Core Team (2009) nlme: Linear and Nonlinear Mixed Effects of Models. R package version 3.1

Porter LJ, Hrstich LN, Chan BG (1986) The conversion of procyanidins and prodelphinidins to cyanidin and delphinidin. Phytochemistry 25:223-230

R Development Core Team (2011) R: A language and environment for statistical computing. Vienna, Austria

Ratledge C, Wilkinson SG (1988) Microbial Lipids. Academic Press, London Scalbert A (1991) Antimicrobial properties of tannins. Phytochemistry 30:3875-3883 
604 Schimel JP, Cates RG, Ruess R (1998) The role of balsam poplar secondary chemicals in 605 controlling soil nutrient dynamics through succession in the Alaskan taiga.

$606 \quad$ Biogeochemistry 42:221-234

607 Smolander A, Kanerva S, Adamczyk B, Kitunen V (2012) Nitrogen transformations in 608 609

610 Strickland MS, Lauber C, Fierer N, Bradford MA (2009) Testing the functional 611

Ushio M, Adams JM (2011) A meta-analysis of the global distribution pattern of

Tabatabai MA, Bremner JM (1969) Use of p-nitrophenyl phosphate for assay of soil phosphatase activity. Soil Biol Biochem 1:301-307 significance of microbial community composition. Ecology 90:441-451. doi:doi:10.1890/08-0296.1 condensed tannins in woody tree leaves. The Open Ecology Journal 4:18-23

Ushio M, Kitayama K, Balser TC (2010a) Tree species effects on soil enzyme activities through effects on soil physicochemical and microbial properites in a tropical montane forest on Mt. Kinabalu, Borneo. Pedobiologia 53:227-233

Ushio M, Kitayama K, Balser TC (2010b) Tree species-mediated spatial patchiness of the composition of microbial community and physicochemical properties in the topsoils of a tropical montane forest. Soil Biol Biochem 42:1588-1595

Ushio M, Miki T, Kitayama K (2009) Phenolic control of plant nitrogen acquisition through the inhibition of soil microbial decomposition processes: a plant-microbe competition model. Microbes Environ 24:180-187

626 Ushio M, Wagai R, Balser TC, Kitayama K (2008) Variations in the soil microbial 
community composition of a tropical montane forest ecosystem: Does tree species matter? Soil Biol Biochem 40:2699-2702

van der Putten WH, Bardgett RD, de Ruiter PC, Hol WHG, Meyer KM, Bezemer TM, Bradford MA, Christensen S, Eppinga MB, Fukami T, Hemerik L, Molofsky J, Schädler M, Scherber C, Strauss SY, Vos M, Wardle DA (2009) Empirical and theoretical challenges in aboveground-belowground ecology. Oecologia 161:1-14

Wardle DA, Bardgett RD, Klironomos JN, Setala H, van der Putten WH, Wall DH (2004) Ecological linkages between aboveground and belowground biota. Science 304:1629-1633

White DC, Davis WM, Nickels JS, King JD, Bobbie RJ (1979) Determination of the sedimentary microbial biomass by extractible lipid phosphate. Oecologia $40: 51-62$

White DC, Ringelberg DB (1998) Signature lipid biomarker analysis. Techniques in Microbial Ecology. Oxford University Press, New York

Wood SN (2004) Stable and efficient multiple smoothing parameter estimation for generalized additive models. Journal of the American Statistical Association 99:673-686

Wurzburger N, Hendrick RL (2009) Plant litter chemistry and mycorrhizal roots promote a nitrogen feedback in a temperate forest. J Ecol 97:528-536

Yao H, He Z, Wilson MJ, Campbell CD (2000) Microbial biomass and community structure in a sequence of soils with increasing fertility and changing land use. Microb Ecol 40:223-237

Zelles L, Rackwitz R, Bai QY, Beck T, Beese F (1995) Discrimination of microbial 
652

653

654 


\section{Figure captions}

656 Fig. 1 Effects of condensed tannins on the soil enzyme activities under field

657 conditions. The white and gray columns indicate the control and tannin-addition

658 treatments, respectively. The initial soil enzyme activities (i.e., before water or tannin

659 addition) are not shown in this figure. $\uparrow P<0.1$ and $* P<0.05$ by paired $t$-test. The bars

660 indicate the SEM.

661 Fig. 2 Effects of condensed tannins on the soil respiration rate under field conditions.

662 The results of the Dacrydium and Lithocarpus soil samples were combined because no

663 significant effect of the tree species on the soil respiration rate was found. Therefore,

664 only the effects of tannin addition are shown here. The white and gray columns indicate

665 the control and tannin-addition treatments, respectively. ${ }^{*} P<0.05$, $* * P=0.01$, by paired

$666 t$-test. The bars indicate the SEM.

667 Fig. 3 Effects of the addition of condensed tannins and duration of incubation on the 668 enzyme activities and respiration rate of the Dacrydium soil samples. The activities of

669 acid phosphatase (a), $\beta$-D-glucosidase (b), $N$-acetylglucosaminidase (c), phenol oxidase

670 (d), and peroxidase, (e) as well as the soil respiration rate (f) are shown. The white and

671 gray symbols indicate the control and tannin-added samples, respectively. Solid lines

672 and dotted lines indicate predicted values of control and tannin treatment, respectively,

673 and they are shown only when effects of tannin-addition or the interaction term were

674 significant. The values were predicted by the additive mixed model. The bars indicate

675 the SEM.

676 Fig. 4 Effects of the addition of condensed tannins and duration of incubation on the

677 enzyme activities and respiration rate of the Lithocarpus soil samples. The activities of 
678 acid phosphatase (a), $\beta$-D-glucosidase (b), $N$-acetylglucosaminidase (c), phenol oxidase

679 (d), and peroxidase (e), as well as the soil respiration rate (f) are shown. The white and 680 gray symbols indicate the control and tannin-added samples, respectively. Solid lines 681 and dotted lines indicate predicted values of control and tannin treatment, respectively, 682 and they are shown only when effects of tannin-addition or the interaction term were 683 significant. The values were predicted by the additive mixed model. The bars indicate 684 the SEM.

685 Fig. 5 Effects of tree species, condensed tannins and incubation time on 686 fungi-to-bacteria ratio. Dacrydium and Lithocarpus soil samples are represented by 687 circles and triangles, respectively. The control and tannin-added samples are represented 688 by white and gray symbols, respectively. Solid lines and dotted lines indicate predicted

689 values of control and tannin treatment, respectively. The bars indicate the SEM. The

690 values were predicted by the additive mixed model. The results of the statistical analyses 691 are shown in Table 1.

692 Fig. 6 Effects of the addition of condensed tannins and tree species on the net 693 nitrogen mineralization rate. The white and gray columns indicate the control and 694 tannin-addition treatments, respectively. ${ }^{*}, \dagger$ indicate significance level at $P<0.05$ by 695 paired $t$-test and $t$-test, respectively. Bars indicate the SEM.

697 Supplementary Figure Captions

698 Fig. S1 Cumulative carbon dioxide respired from soil samples in the laboratory 699 experiment. The white and gray bars indicate the control and tannin-addition treatments. 700 The bars indicate the SEM. The results of the statistical analyses are shown in Table 2. 

(a) Acid phosphatase

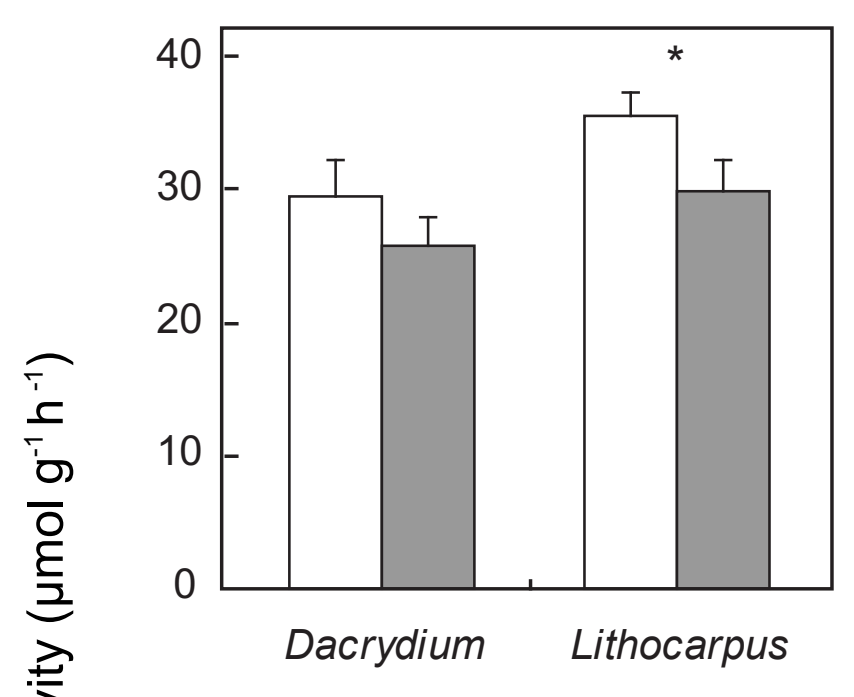

(d) Phenol oxidase

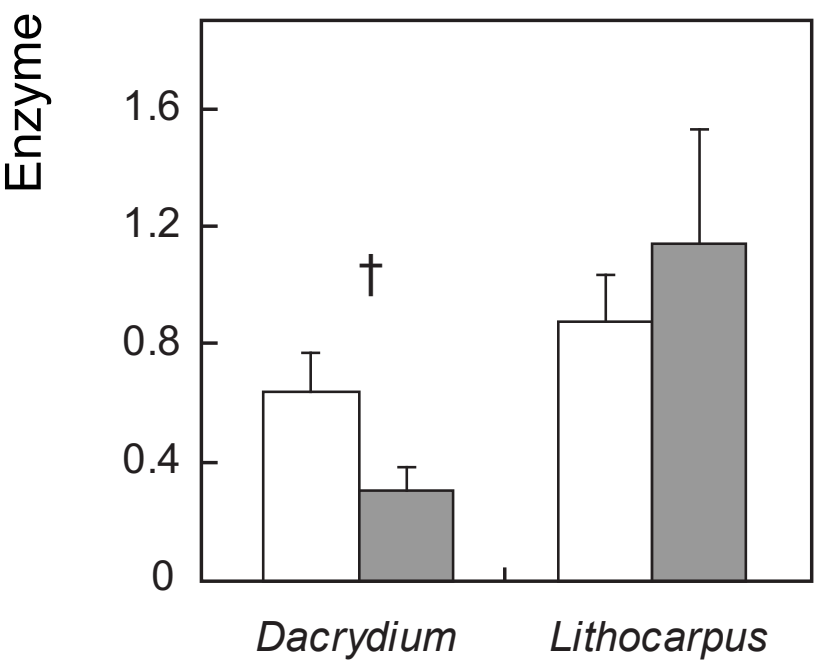

(b) $\beta$-D-Glucosidase

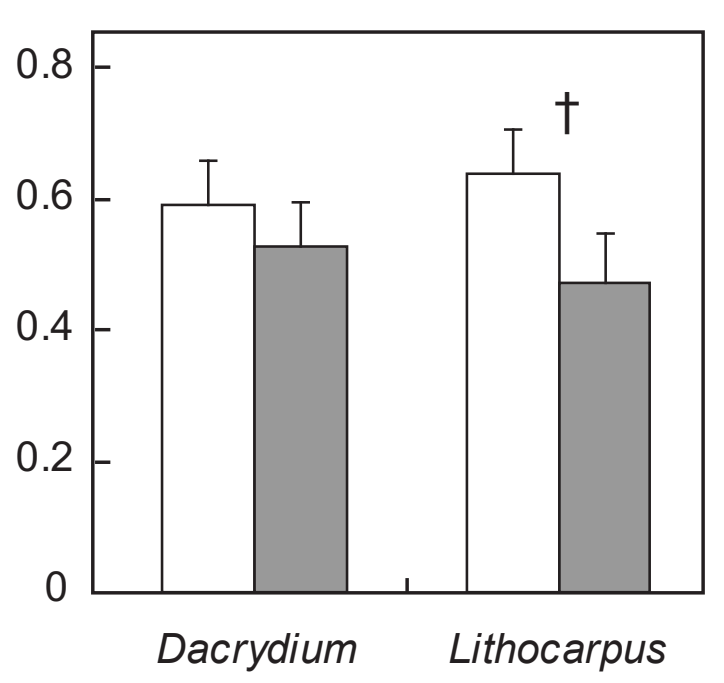

(e) Peroxidase

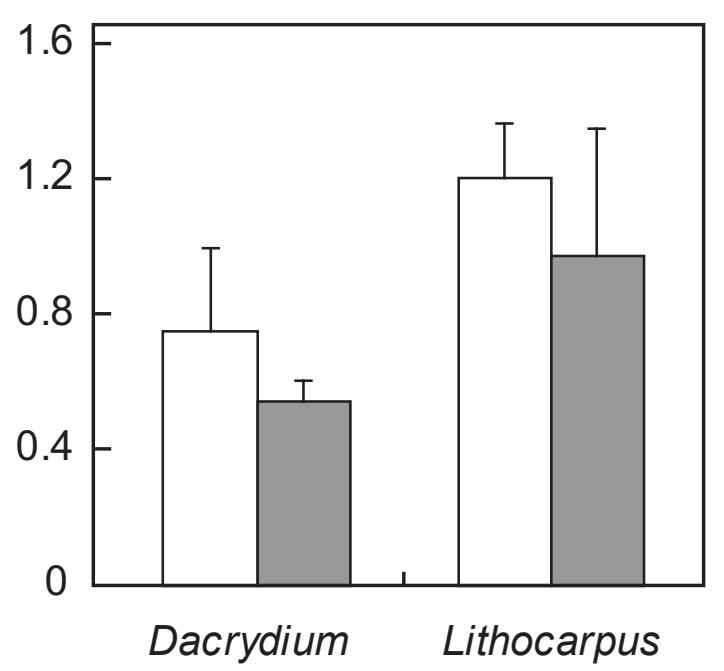

(c) N-Acetylglucosaminidase

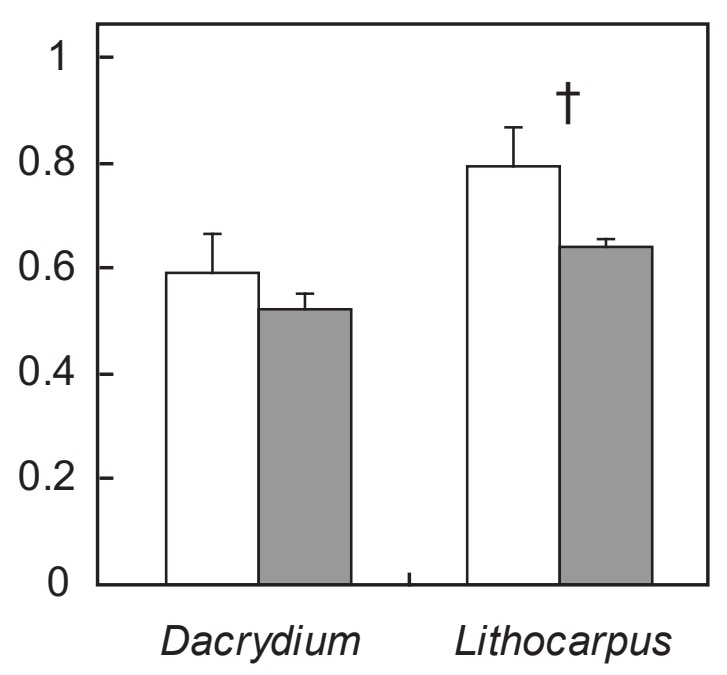

$\square$ Control

Tannin added

Fig. 1 Ushio et al. 
Soil respiration rate

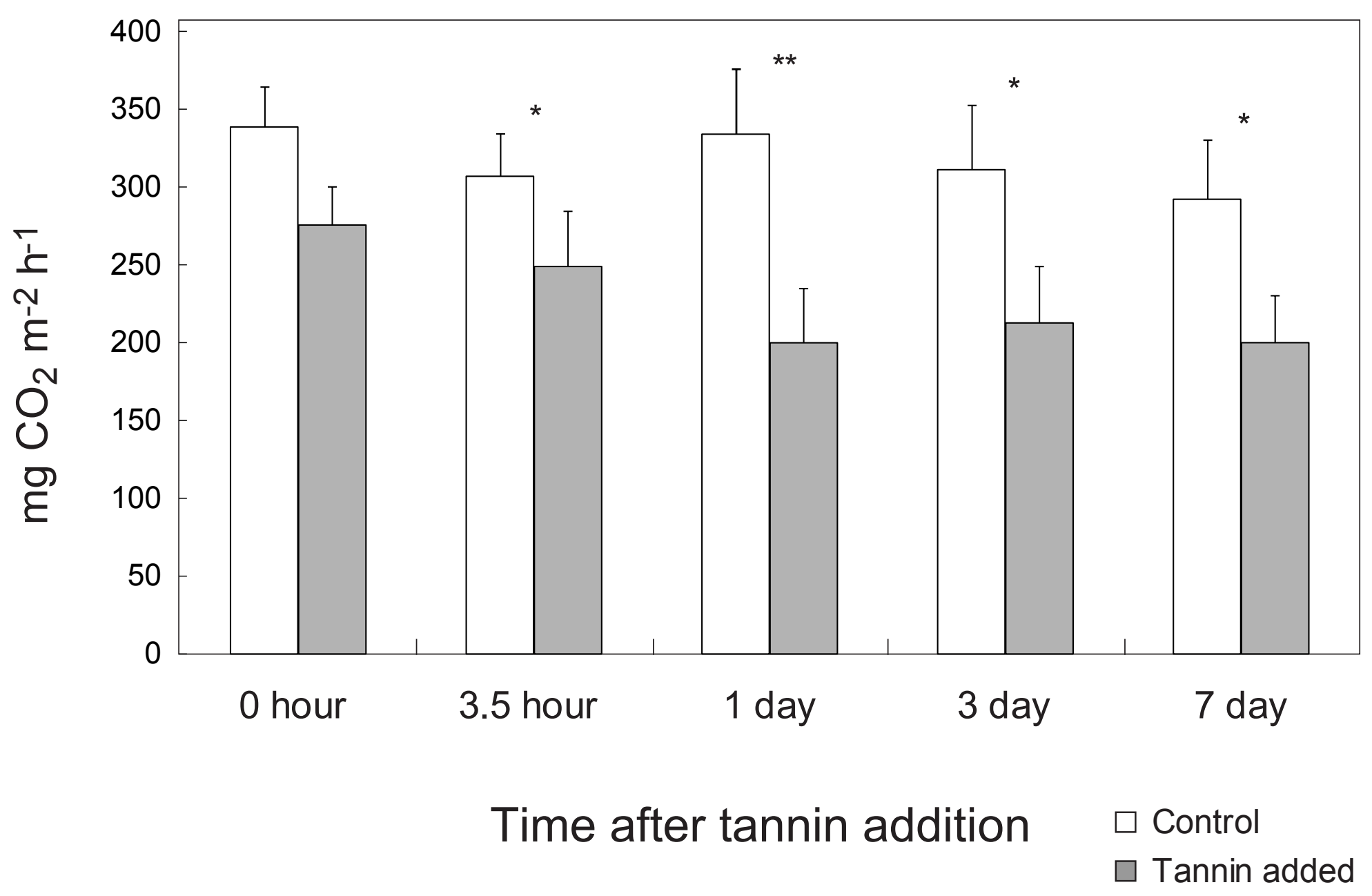

Fig. 2 Ushio et al. 
(a) Acid phosphatase

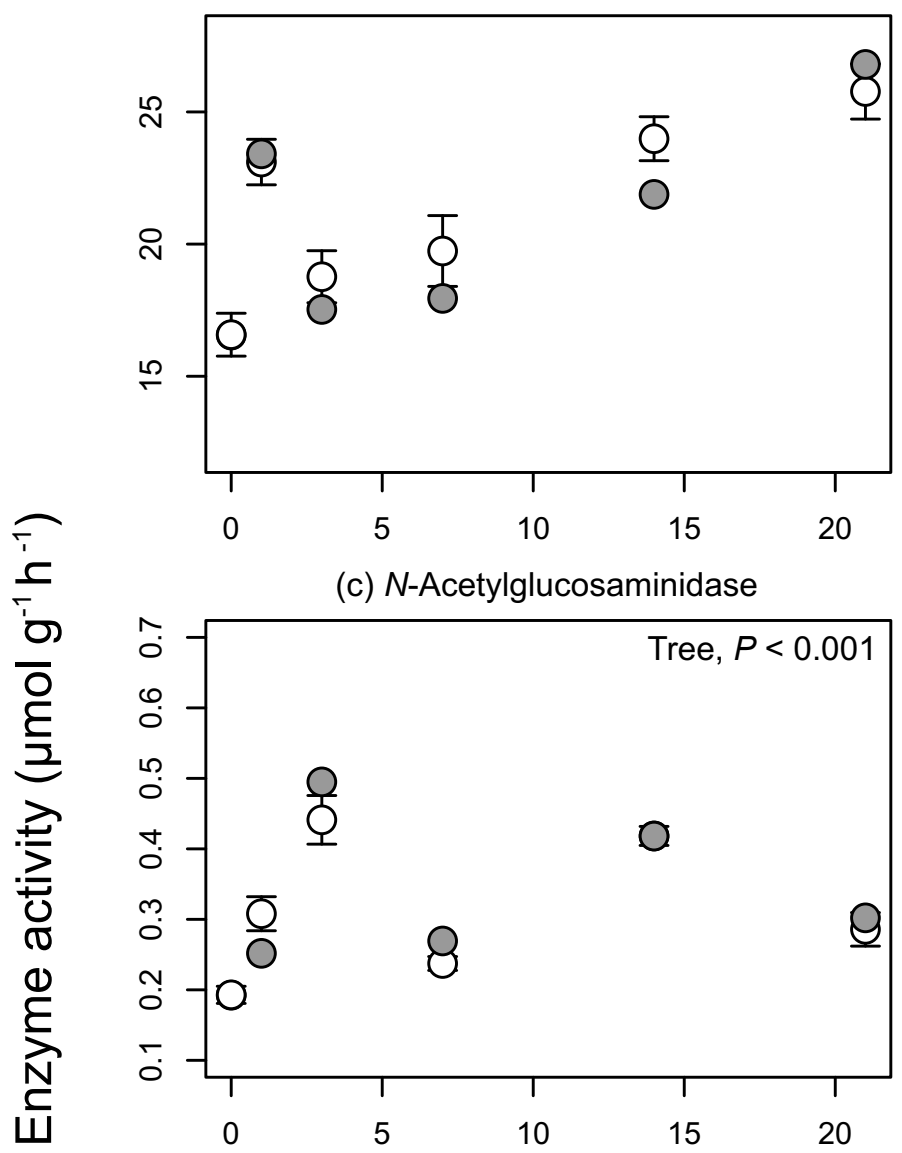

(e) Peroxidase

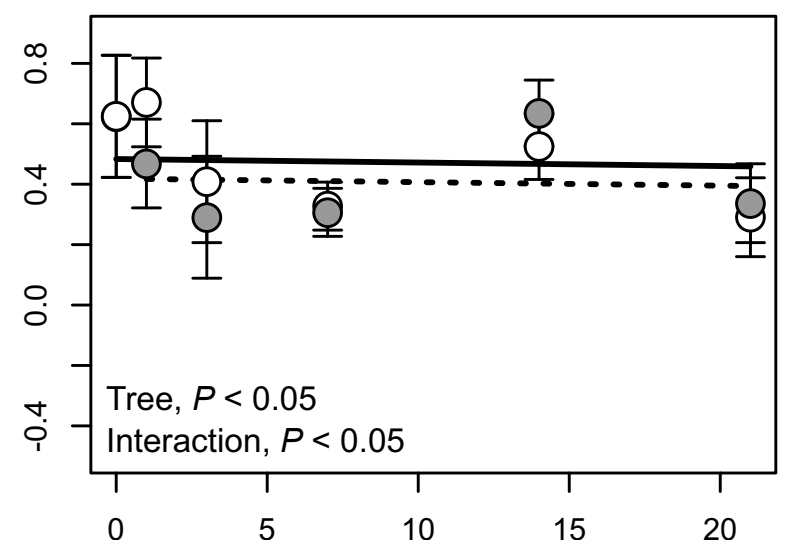

(b) $\beta$-D-Glucosidase

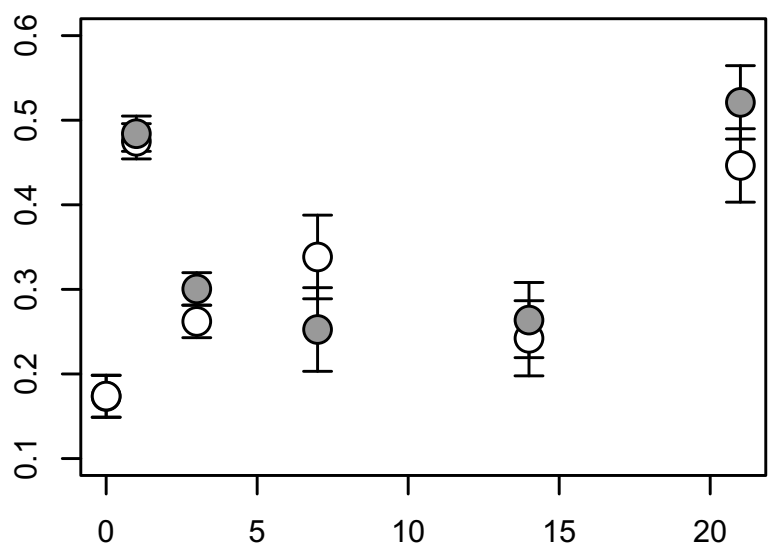

(d) Phenol oxidase

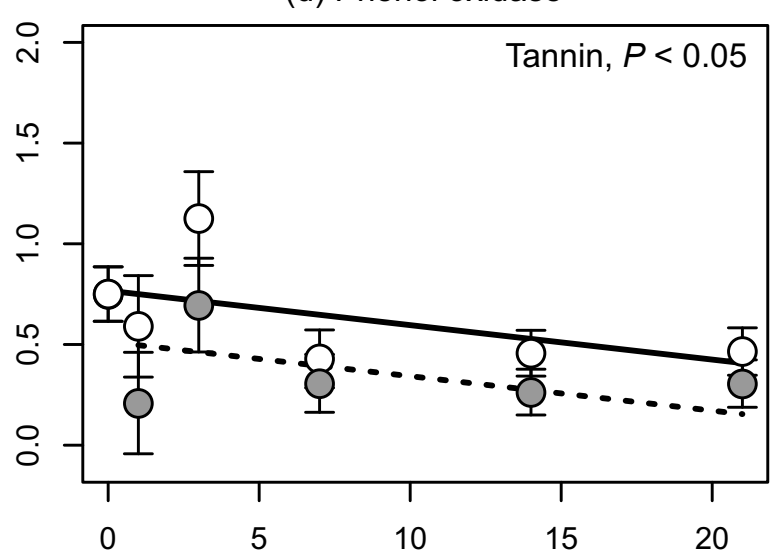

(f) Soil respiration rate

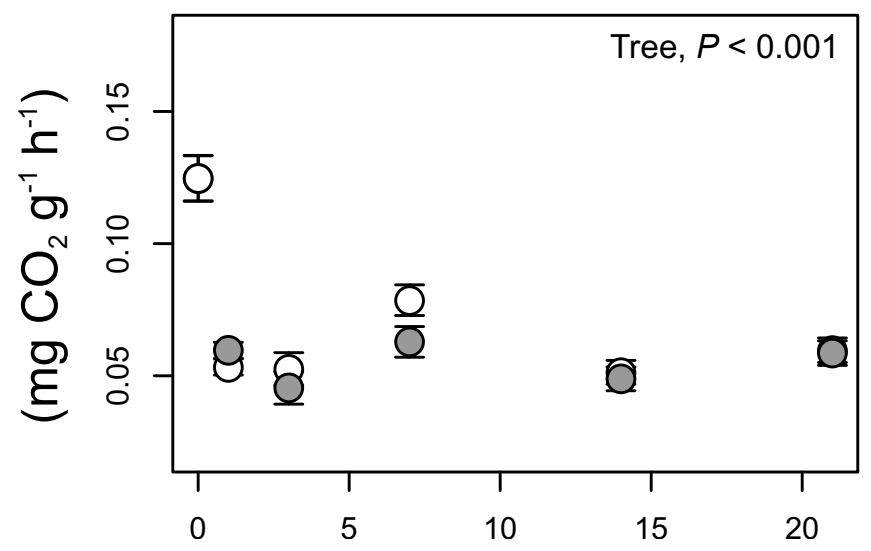

Dacrydium + Control

Dacrydium + Tannin 
(a) Acid phosphatase

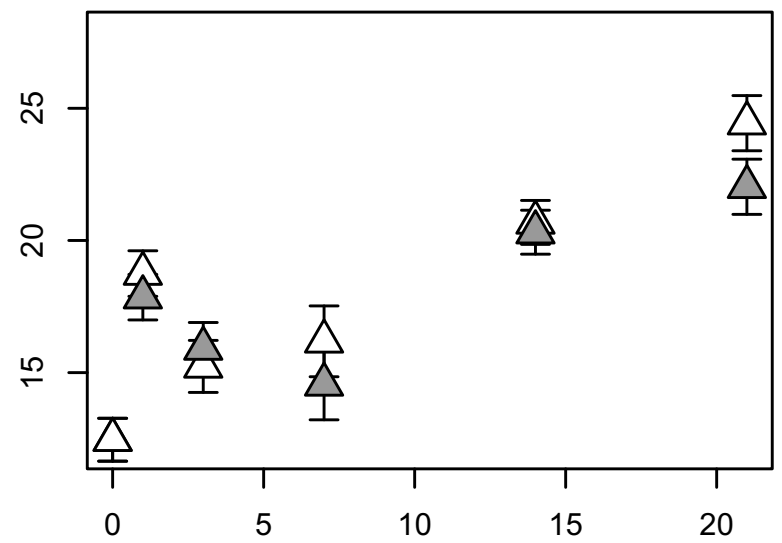

(c) N-Acetylglucosaminidase

בَ'

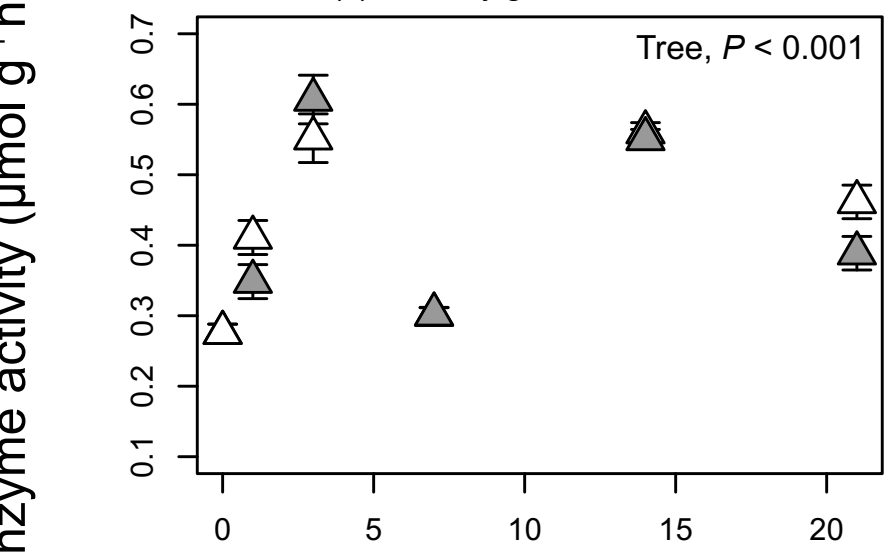

(e) Peroxidase

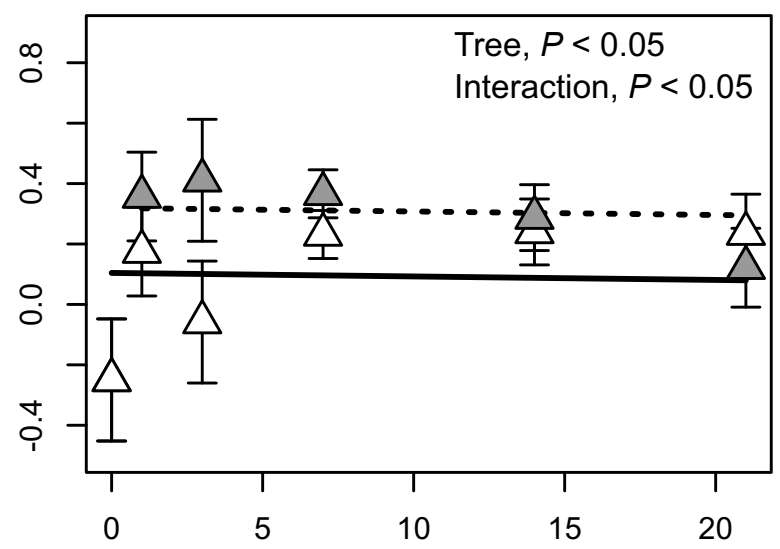

(b) $\beta$-D-Glucosidase

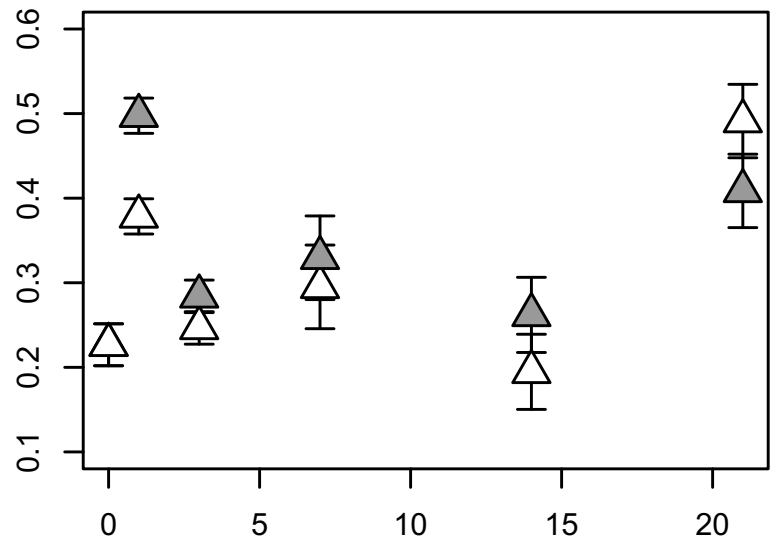

(d) Phenol oxidase

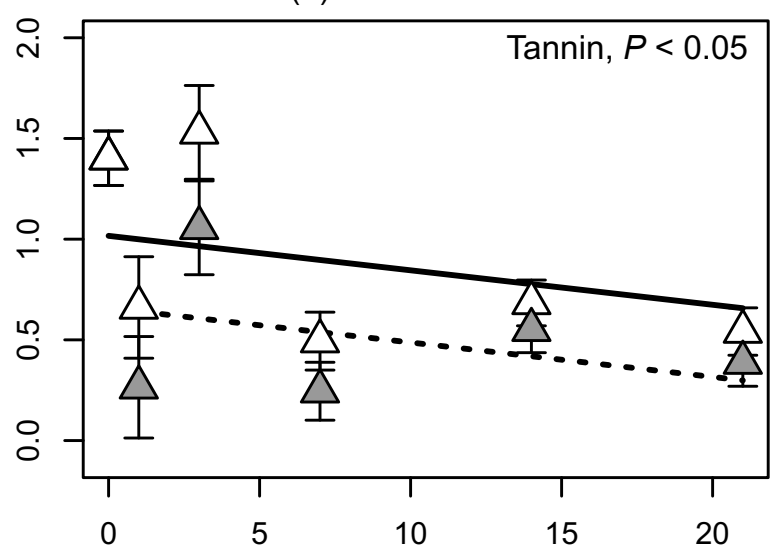

(f) Soil respiration rate

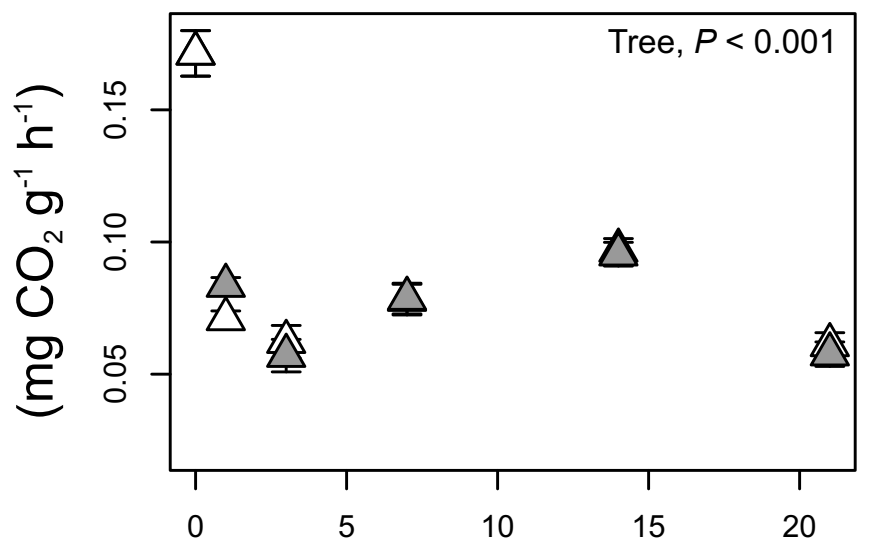

$\triangle$ Lithocarpus + Control $\triangle$ Lithocarpus + Tannin 


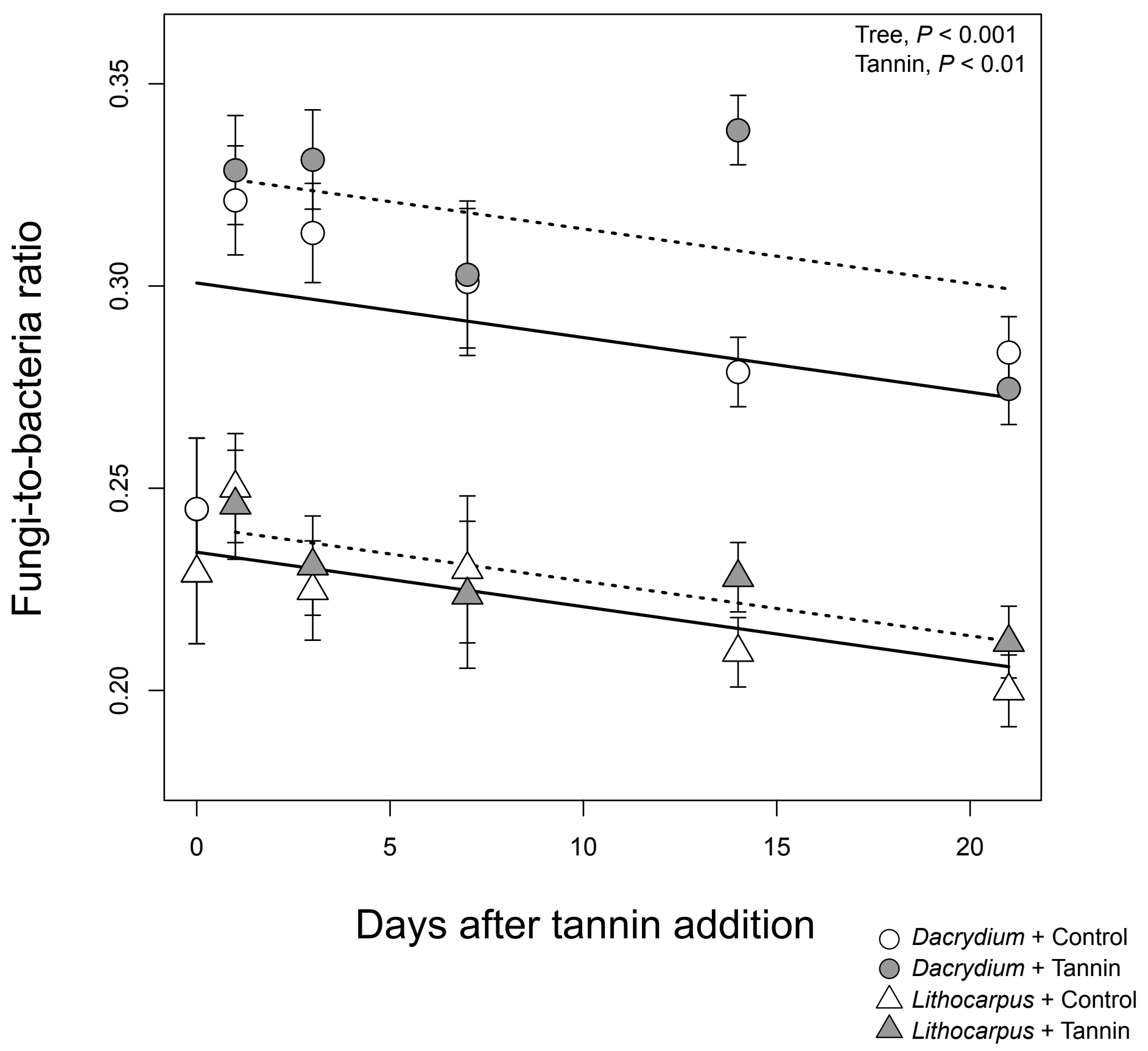

Fig. 5 Ushio et al. 


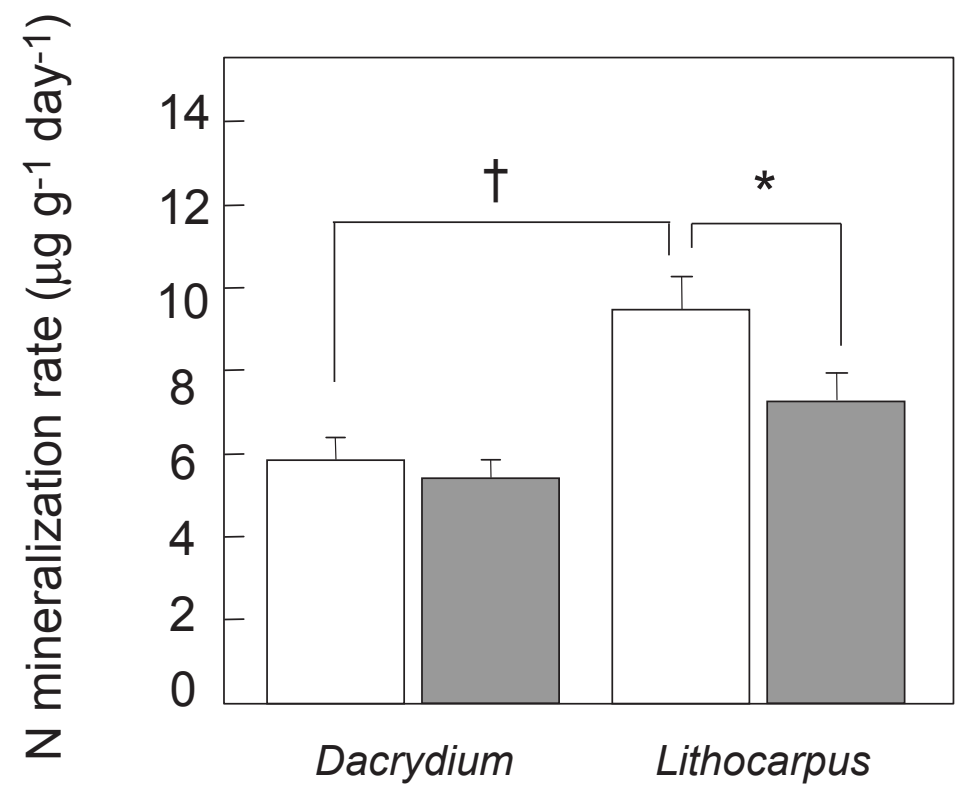

$\square$ Control

Tannin added

Fig. 6 Ushio et al. 


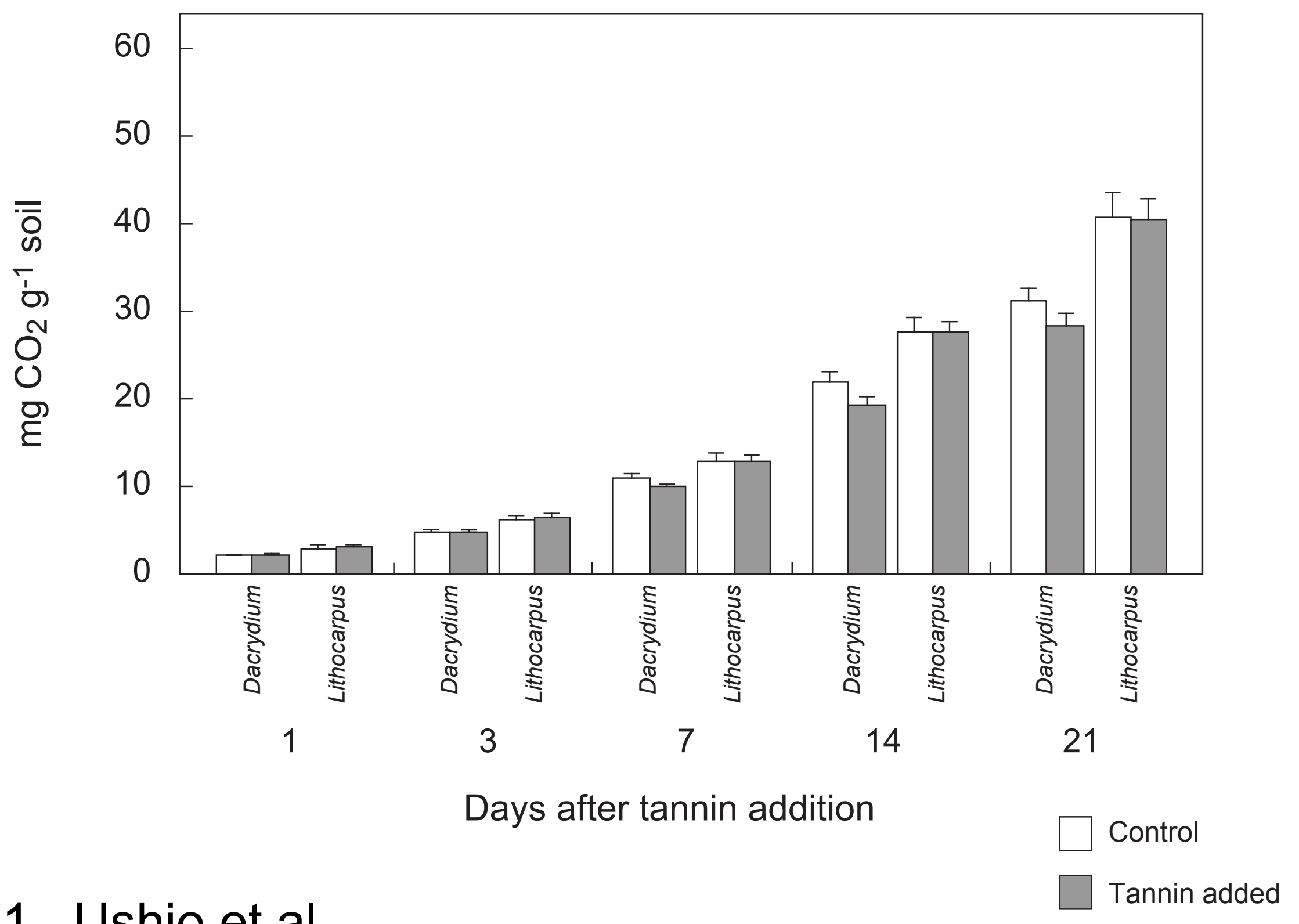

Fig. S1 Ushio et al. 
701 Table 1 Coefficients and significance by linear mixed models in the tannin addition experiment under field condition

\begin{tabular}{|c|c|c|c|c|c|}
\hline Effects & Intercept & Unit & Tree & Tannin & Interaction term \\
\hline \multicolumn{6}{|l|}{ Soil microbial property } \\
\hline Total lipid & 1741 & $\left(\mathrm{nmol} \mathrm{g}^{-1}\right)$ & -318 & -352 & 233 \\
\hline Fungi/Bacteria ratio & 0.459 & & $* *_{-0.174}$ & -0.070 & 0.024 \\
\hline $\mathrm{Gm}+/ \mathrm{Gm}-$ ratio & 2.528 & & 0.261 & 0.162 & $\dagger-0.307$ \\
\hline Lipid profile PC1 (40.6\%) & -0.012 & & 0.057 & -0.013 & -0.041 \\
\hline Lipid profile PC2 (18.2\%) & 0.091 & & $* * *$-0.198 & 0.006 & 0.020 \\
\hline Lipid profile PC3 (10.5\%) & -0.002 & & 0.010 & 0.010 & -0.033 \\
\hline \multicolumn{6}{|l|}{ Soil mineralization activity } \\
\hline Acid phosphatase & 29.5 & $\left(\mu \mathrm{mol} \mathrm{g}^{-1} \mathrm{~h}^{-1}\right)$ & 6.061 & $* \mathbf{- 3 . 7 5 7}$ & -1.947 \\
\hline$\beta$-D-Glucosidase & 0.589 & $\left(\mu \mathrm{mol} \mathrm{g}{ }^{-1} h^{-1}\right)$ & 0.048 & $*_{-0.061}$ & -0.106 \\
\hline$N$-Acetylglucosaminidase & 0.590 & $\left(\mu \mathrm{mol} \mathrm{g}^{-1} \mathrm{~h}^{-1}\right)$ & $* 0.206$ & $\dagger-0.067$ & -0.090 \\
\hline Phenol oxidase & 0.644 & $\left(\mu \mathrm{mol} \mathrm{g}^{-1} \mathrm{~h}^{-1}\right)$ & $\dagger 0.242$ & -0.335 & $\dagger 0.599$ \\
\hline Peroxidase & 0.752 & $\left(\mu \mathrm{mol} \mathrm{g}{ }^{-1} h^{-1}\right)$ & 0.453 & -0.205 & -0.025 \\
\hline Soil respiration rate $\S$ & 320 & $\left(\mathrm{mg} \mathrm{CO}_{2} \mathrm{~m}^{-2} \mathrm{~h}^{-1}\right)$ & -24.9 & $*-109$ & 35.1 \\
\hline \multicolumn{6}{|l|}{ Soil physical property } \\
\hline $\mathrm{pH}\left(\mathrm{H}_{2} \mathrm{O}\right)$ & 4.050 & & $* 0.304$ & 0.228 & $*_{-0.274}$ \\
\hline $\mathrm{pH}(\mathrm{KCl})$ & 3.196 & & 0.206 & 0.066 & -0.156 \\
\hline
\end{tabular}

Coefficients were estimated by the following statistical model formula: (Explained variable) $=$ Intercept + Tree coefficient $\times($ Dacrydium $[0]$ or Lithocarpus [1] $)+$ Tannin coefficient $\times($ Control [0] or Tannin [1] $)+$ Interaction term + residuals. Therefore, intercepts indicate the mean values calculated by including all treatments (i.e., two tree species and two experimental treatments). Zero and one are dummy variables. $\dagger P<0.10, * P$ $<0.05, * * P<0.01, * * * P<0.001$. §Additive mixed model was applied only for the soil respiration rate because the respiration rate was monitored periodically. 
707 Table 2 Coefficients and significance by additive mixed models in the tannin addition experiment under laboratory condition

\begin{tabular}{|c|c|c|c|c|c|c|}
\hline Soil properties & Intercept & Unit & Tree & Tannin & Interaction term & Days \\
\hline \multicolumn{7}{|l|}{ Soil microbial property } \\
\hline Total lipid & 1998 & $\left(\mathrm{nmol} \mathrm{g}{ }^{-1}\right)$ & -234 & -38.4 & 122 & $* * * *$ \\
\hline Fungi/Bacteria ratio & 0.289 & & $* * *-0.067$ & $* * 0.027$ & -0.021 & $* * *$ \\
\hline $\mathrm{Gm}+/ \mathrm{Gm}-$ ratio & 1.546 & & 0.055 & $\dagger-0.063$ & 0.035 & $* * *$ \\
\hline Lipid profile PC1 (39.8\%) & -0.100 & & $* * * 0.221$ & -0.034 & 0.020 & \\
\hline Lipid profile PC2 (21.8\%) & -0.047 & & 0.075 & $* * 0.027$ & -0.014 & * \\
\hline Lipid profile PC3 (9.5\%) & -0.025 & & 0.045 & 0.015 & -0.021 & $* * * *$ \\
\hline \multicolumn{7}{|l|}{ Soil mineralization activity } \\
\hline Acid phosphatase & 21.777 & $\left(\mu \mathrm{mol} \mathrm{g} \mathrm{g}^{-1} \mathrm{~h}^{-1}\right)$ & -3.365 & -0.793 & -0.029 & $* * * *$ \\
\hline$\beta$-D-Glucosidase & 0.333 & $\left(\mu \mathrm{mol} \mathrm{g} \mathrm{g}^{-1} \mathrm{~h}^{-1}\right)$ & -0.018 & 0.021 & 0.009 & $* * * *$ \\
\hline$N$-Acetylglucosaminidase & 0.326 & $\left(\mu \mathrm{mol} \mathrm{g} \mathrm{g}^{-1} \mathrm{~h}^{-1}\right)$ & $* * * 0.113$ & 0.006 & -0.022 & $* * * *$ \\
\hline Phenol oxidase & 0.624 & $\left(\mu \mathrm{mol} \mathrm{g} \mathrm{g}^{-1} \mathrm{~h}^{-1}\right)$ & 0.249 & $*_{-0.253}$ & -0.105 & $* *$ \\
\hline Peroxidase & 0.474 & $\left(\mu \mathrm{mol} \mathrm{g} \mathrm{g}^{-1} \mathrm{~h}^{-1}\right)$ & $*_{-\mathbf{0}} \mathbf{0 . 3 7 9}$ & -0.065 & $* 0.280$ & \\
\hline Soil respiration rate & 0.064 & $\left(\mathrm{mg} \mathrm{CO} \mathrm{CO}_{2} \mathrm{~g}^{-1}\right)$ & $* * * 0.020$ & -0.002 & -0.001 & $* * * *$ \\
\hline Cumulative $\mathrm{CO}_{2}$ & 12.975 & $\left(\mathrm{mg} \mathrm{CO}_{2} \mathrm{~g}^{-1}\right)$ & $* * 3.218$ & $\dagger-1.430$ & $\dagger 1.925$ & $* * * *$ \\
\hline \multicolumn{7}{|l|}{ Soil physical property } \\
\hline $\mathrm{pH}\left(\mathrm{H}_{2} \mathrm{O}\right)$ & 3.937 & & $\dagger 0.099$ & $* * 0.046$ & $*_{-0.051}$ & $* * * *$ \\
\hline $\mathrm{pH}(\mathrm{KCl})$ & 3.010 & & 0.042 & $* * *_{\mathbf{-}} \mathbf{0 . 0 2 3}$ & $\dagger 0.015$ & $* * * *$ \\
\hline
\end{tabular}

Coefficients were estimated by the following statistical model formula: (Explained variable) $=$ Intercept + Tree coefficient $\times($ Dacrydium $[0]$ or 
712 Table S1 Intact soil physicochemical properties and enzyme activity

\begin{tabular}{|c|c|c|c|}
\hline \multicolumn{2}{|l|}{ Tree species } & $\begin{array}{l}\text { Dacrydium gracilis } \\
\text { (conifer) }\end{array}$ & $\begin{array}{c}\text { Lithocarpus clementianus } \\
\text { (broadleaf) }\end{array}$ \\
\hline \multicolumn{4}{|c|}{ Soil phycicochemical properties } \\
\hline Soil Water Content & $(\%)$ & $79.0(0.36)$ & $79.3(1.22)$ \\
\hline $\mathrm{pH}\left(\mathrm{H}_{2} \mathrm{O}\right)$ & & $3.90(0.05)^{*}$ & $4.08(0.05)$ \\
\hline $\mathrm{pH}(\mathrm{KCl})$ & & $3.08(0.06)$ & $3.13(0.05)$ \\
\hline Total phenol ${ }^{1}$ & $\left(\mu \mathrm{g} \mathrm{g}^{-1}\right)$ & $3.65(0.39)$ & $4.52(0.75)$ \\
\hline Condensed tannins ${ }^{1}$ & $\left(\mu \mathrm{g} \mathrm{g}^{-1}\right)$ & $0.37(0.08) \dagger$ & $0.20(0.04)$ \\
\hline \multicolumn{4}{|l|}{ Soil microbial community } \\
\hline Total lipid abundance ${ }^{2}$ & $\left(\mathrm{nmol} \mathrm{g}^{-1}\right)$ & $2309(240)$ & 1799 (336) \\
\hline Fungi/Bacteria ratio ${ }^{2}$ & & $0.462(0.038)^{* * *}$ & $0.313(0.023)$ \\
\hline $\mathrm{Gm}+/ \mathrm{Gm}-$ ratio $^{2}$ & & $1.552(0.123)$ & $1.481(0.101)$ \\
\hline \multicolumn{4}{|l|}{ Soil enzyme activity } \\
\hline Acid phosphatase & $\left(\mu \mathrm{mol} \mathrm{g}{ }^{-1} \mathrm{~h}^{-1}\right)$ & $16.6(0.81)$ & $12.5(2.18)$ \\
\hline$\beta$-D-glucosidase & $\left(\mu \mathrm{mol} \mathrm{g}{ }^{-1} h^{-1}\right)$ & $0.174(0.025)$ & $0.227(0.057)$ \\
\hline$N$-Acetylglucosamidase & $\left(\mu \mathrm{mol} \mathrm{g} \mathrm{g}^{-1} \mathrm{~h}^{-1}\right)$ & $0.193(0.012)^{* * *}$ & $0.276(0.016)$ \\
\hline Phenol oxidase & $\left(\mu \mathrm{mol} \mathrm{g}{ }^{-1} h^{-1}\right)$ & $0.750(0.135)$ & $1.402(0.316)$ \\
\hline Peroxidase & $\left(\mu \mathrm{mol} \mathrm{g}{ }^{-1} h^{-1}\right)$ & $0.625(0.202)$ & N.D. \\
\hline \multicolumn{4}{|l|}{ Soil $C$ and $N$ flux } \\
\hline $\mathrm{N}$ mineralization rate & $\left(\mu \mathrm{g} \mathrm{g}^{-1} \mathrm{~d}^{-1}\right)$ & $5.85(0.55)^{* *}$ & $9.48(0.79)$ \\
\hline Nitrification rate & $\left(\mu \mathrm{g} \mathrm{g}^{-1} \mathrm{~d}^{-1}\right)$ & $0.04(0.08)$ & $0.29(0.21)$ \\
\hline Soil respiration rate & $\left(\mathrm{mg} \mathrm{CO} 2 \mathrm{~g}^{-1} \mathrm{~h}^{-1}\right)$ & $0.125(0.009) \dagger$ & $0.171(0.021)$ \\
\hline
\end{tabular}

713 'data of the surface organic soil beneath each tree crown, from Ushio et al. 2010. ${ }^{2}$ data modified from

714 Ushio et al. 2008. Values of the soil enzyme activities and carbon and nitrogen flux were measured for 715 soil samples used for the laboratory incubation experiment before the incubation. Parentheses indicate 716 standard error of mean. Significant differences between the two species were indicated by $\uparrow P<0.1, * P$ $717<0.05$ and $* * P<0.01$ (t-test) 
718 Table S2 $F$-values by linear mixed models in the tannin addition experiment under field condition

\begin{tabular}{llll}
\hline Effects & Tree & Tannin & Tree $\times$ Tannin \\
\hline Degree of freedom & 1 & 1 & 1
\end{tabular}

Soil microbial property

$\begin{array}{llll}\text { Total lipid } & 0.734 & 2.904 & 0.707 \\ \text { Fungi/Bacteria ratio } & \mathbf{1 4 . 7 8}^{* *} & 2.497 & 0.102 \\ \text { Gm+/Gm- ratio } & 0.268 & 0.013 & \mathbf{4 . 4 2 0} \dagger \\ \text { Lipid profile PC1 }(40.6 \%) & 0.113 & 1.771 & 0.656 \\ \text { Lipid profile PC2 }(18.2 \%) & \mathbf{3 3 . 3 6} * * * & 1.511 & 0.585 \\ \text { Lipid profile PC3 }(10.5 \%) & 0.015 & 0.238 & 1.662\end{array}$

Soil mineralization activity

$\begin{array}{llll}\text { Acid phosphatase } & 3.280 & \mathbf{8 . 1 9 4} * & 0.347 \\ \beta \text {-D-glucosidase } & 0.003 & \mathbf{6 . 3 8 9}^{*} & 1.369 \\ N \text {-acetylglucosamidase } & \mathbf{9 . 4 8 5} * & \mathbf{4 . 4 0 3}^{*} & 0.653 \\ \text { Phenol oxidase } & \mathbf{3 . 7 2 1} \dagger & 0.062 & \mathbf{4 . 4 9 7 \dagger} \\ \text { Peroxidase } & 2.358 & 1.325 & 0.004 \\ \text { Soil respiration rate } \S & 0.902 & \mathbf{1 3 . 5 1 *} & 0.715\end{array}$

Soil physical property

\begin{tabular}{|c|c|}
\hline pH (H2O) & $7.307 *$ \\
\hline
\end{tabular}

719 Values indicate $F$-statistics. $\dagger P<0.10, * P<0.05$, ** $P<0.01$, *** $P<0.001$. §Additive mixed model

720 was applied only for the soil respiration rate because the respiration rate was monitored periodically. 
721 Table S3 F-values by additive mixed models in the tannin addition experiment under laboratory 722 condition

\begin{tabular}{lllll}
\hline Soil properties & Tree & Tannin & Tree $\times$ Tannin & Days \\
\hline Degree of freedom & 1 & 1 & 1 & $\S$
\end{tabular}

Soil microbial property

Total lipid

1.694

0.143

0.747

$14.92 * * * *$

Fungi/Bacteria ratio

$20.20 * * *$

$8.864 * *$

2.610

$10.15 * * *$

$\mathrm{Gm}+/ \mathrm{Gm}-$ ratio

0.503

$3.902 \dagger$

0.595

$13.56 * * *$

Lipid profile PC1 (39.8\%)

$59.12 * * *$

2.448

0.431

2.527

Lipid profile PC2 (21.8\%)

1.519

8.062**

1.073

4.672*

Lipid profile PC3 (9.5\%)

2.174

1.951

1.811

$12.76 * * * *$

Soil mineralization activity

Acid phosphatase

1.505

2.599

0.002

75.18****

$\beta$-D-glucosidase

0.127

0.762

0.076

28.0*****

$\mathrm{N}$-acetylglucosamidase

$11.75 * * *$

0.131

0.796

$61.81 * * * *$

Phenol oxidase

1.695

5.198*

0.447

$10.76 * *$

Peroxidase

4.140*

0.469

4.380*

0.068

Soil respiration rate

$13.28 * * *$

0.105

0.015

$38.25 * * * *$

Cumulative $\mathrm{CO}_{2}$

$10.78 * *$

3.536†

$3.221 \dagger$

$2169 * * * *$

Soil physical property

$\mathrm{pH}(\mathrm{H} 2 \mathrm{O})$

$\mathbf{3 . 8 0 1} \dagger$

$7.098 * *$

4.581*

$10.02 * * * *$

$\mathrm{pH}(\mathrm{KCl})$

0.429

13.62***

$3.052 \dagger$

383.3****

Values indicate $F$-statistics. $\dagger P<0.10, * P<0.05, * * P<0.01, * * * P<0.001, * * * * P<0.0001$.

$\S$ Degree of freedom for days is not shown because additive mixed modeling does not calculate a degree

of freedom for a term for which the smoothing function applied. 